\title{
Potent Anti-Cancer Properties of Phthalimide-Based Curcumin Derivatives on Prostate Tumor Cells
}

\author{
Silvia Belluti ${ }^{1}$, Giulia Orteca ${ }^{2}$, Valentina Semeghini ${ }^{1}$, Giovanna Rigillo ${ }^{1}$, Francesca Parenti ${ }^{2}$, \\ Erika Ferrari ${ }^{2, *(\mathbb{D})}$ and Carol Imbriano ${ }^{1, * \mathbb{D}}$ \\ 1 Department of Life Sciences, University of Modena and Reggio Emilia, via Campi 213/D, 41125 Modena, \\ Italy; silvia.belluti@unimore.it (S.B.); valentina.semeghini@unimore.it (V.S.); \\ giovanna.rigillo@unimore.it (G.R.) \\ 2 Department of Chemical and Geological Sciences, University of Modena and Reggio Emilia, via Campi 103, \\ 41125 Modena, Italy; giulia.orteca@unimore.it (G.O.); francesca.parenti@unimore.it (F.P.) \\ * Correspondence: erika.ferrari@unimore.it (E.F.); carol.imbriano@unimore.it (C.I.); \\ Tel.: +39-059-2058631 (E.F.); +39-059-2055542 (C.I.)
}

Received: 31 October 2018; Accepted: 18 December 2018; Published: 21 December 2018

\begin{abstract}
Metastatic castration-resistant prostate cancer is commonly treated with chemotherapy, whose effect is less than satisfactory. This raised the need for novel agents for the treatment of prostate cancer. In the present study, five phthalimide-based curcumin derivatives were synthesized and completely characterized to assess improved stability, pharmacodynamics, and radical scavenging ability. To investigate the potential application in anti-cancer therapy, the anti-proliferative activity of the synthesized molecules was determined on aggressive prostate tumor cells. We demonstrated that the K3F21 derivative has increased potency compared to curcumin, in terms of GI50, anti-proliferative and anti-migrating activities. K3F21 inhibits anchorage-dependent and -independent growth of prostate cancer cells by altering the expression of key genes controlling cell proliferation, such as Cylins D1, B1 and B2, and apoptosis, among which Puma, Noxa, and Bcl-2 family members. Finally, the anti-cancer activity of K3F21 was demonstrated by the analysis of cancer-associated PI3K/AKT, ERK, and p38 signaling pathways.
\end{abstract}

Keywords: curcuminoids; prostate cancer; cell proliferation; anti-cancer drugs; phthalimide

\section{Introduction}

Prostate cancer (PCa) is the second most commonly diagnosed cancer and leading cause of cancer death in western males [1]. The progression from normal prostate to prostatic intraepithelial neoplasia (PIN) and localized adenocarcinoma occurs over many years. Adenocarcinoma is a slow-growing tumor and progression to advanced and metastatic cancer is a relatively late process. Androgen deprivation therapy (ADT), the gold standard for the treatment of advanced PCa, has initial response rates of about $80-90 \%$, but nearly all men eventually develop castration-resistant PCa (CRPC), which is currently incurable [2]. CRPC is commonly treated with different approaches: taxane chemotherapy (such as docetaxel and cabazitaxel), secondary hormonal therapeutic agents (abiraterone and enzalutamide), cellular immunotherapy (sipuleucel-T), or radiotherapy (radium-223). Despite this, inevitable progression of disease frequently occurs [3,4]. A considerable number of novel agents are currently under investigation worldwide to cure PCa and metastatic CRPC [5].

Curcumin (1,7-bis [4-hydroxy-3-methoxyphenyl]-1,6-heptadiene-3,5-Dione), a polyphenol obtained from the rhizome Curcuma longa L., and its analogs have shown anti-cancer properties by suppressing tumor initiation and progression [6,7], through the modulation of multiple signaling pathways and the inhibition of cell proliferation, invasion, metastasis, and angiogenesis [8]. 
Curcumin has demonstrated chemopreventive and chemotherapeutic activity also in PCa. In vitro, it reduces the expression of androgen receptors (AR), which appears to enhance the progression of PCa to the hormone refractory state CRPC [9]. Experiments performed on LNCaP, PC3, and DU145, metastatic PCa cells from lymph node, bone, and brain, respectively, showed that curcumin impacts on cell proliferation by decreasing the expression of epidermal growth factor receptor (EGFR) and cell cycle cyclins. Moreover, curcumin anti-proliferative activity has been associated to increased expression of the cyclin dependent inhibitors (CDKs) p21, p27, and p16, both in vitro and in vivo. Curcumin targets various signaling pathways, among which the PI3K/AKT network, commonly constitutively activated in PCa (for a review see [10]). Interestingly, curcumin has been recently found to affect cancer associated fibroblast (CAF)-driven PCa invasion, promoted by prostate tumor-stromal interaction, through the inhibition of the MAOA/mTOR/HIF- $1 \alpha$ signaling pathway [11]. These data pointed at curcumin as a protective molecule against the epithelial to mesenchymal transition (EMT), a highly complex process allowing the cells to escape from the primary tumor and disseminate at distant sites.

Despite the proven efficacious anti-proliferative properties of curcumin against cancer cells in vitro and in vivo, there is currently no approved health claim for this molecule [12]. The main controversial dark side of this polyphenol is its apparent instability in physiological environment. This limits a possible successful and controlled application in clinics and does not allow to fully understand which mechanisms are activated by the molecule and which by its metabolites. It is therefore crucial to identify stable derivatives and characterize their molecular basis of action against cancer cell proliferation and metastatization. Recently, Nelson et al. [13] pinpointed the main concerns in selecting curcumin as pharmaceutical lead compound. However, a wide slice of the scientific community does not completely agree with this lapidary verdict [14-17]. In this landscape, we devoted research efforts to develop new stable curcumin analogs based on phtalimide (K3F).

Phthalimide-based drugs firstly appeared in the late 1950s and Thalidomide, the most notable one, was prescribed to pregnant women as a sedative and anti-emetic agent. The benefits of this compound were soon darkened by the discovery of its teratogenicity that forced its withdrawal from market. Today, Thalidomide is used in the treatment of erythema nodosum leprosum, multiple myeloma, myelodysplastic syndrome, and shows promising properties in the treatment of autoimmune disorders [18]. Recently, the identification of the basis for its teratogenicity has allowed the development of new thalidomide derivatives without teratogenic activity [19]. Early clinical trials showed that thalidomide has clinical anti-tumor activity in hormone-refractory PCa [20], therefore the development of analogues and/or its administration in conjunction with other anti-cancer agents are under exploration in order to improve its efficacy and reduce toxicity.

Here, we describe the synthesis, chemical and pharmacokinetic characterization, and anti-proliferative activity of new phthalimide-based curcumin derivatives on human PCa cells.

\section{Results}

\subsection{Synthesis and Characterization}

The synthesis of curcumin-like structures is commonly performed by one-pot "Pabon reaction" [21] or its modifications [22]. The reaction proceeds through the complexation of boron by acetyl-acetone (acac), or another $\beta$-diketone, in order to protect the methylenic carbon and activate the side methyl groups as nucleophiles. In a further step, Knoevenagel condensation takes place with vanillin or other selected benzaldehydes. Finally, when the reaction is accomplished in $\mathrm{N}, \mathrm{N}$-dimethylformamide (DMF), the product separates by acidification with hydrochloric acid. In order to obtain the phthalimide-based curcuminoids (Figure 1), acac was functionalized by $\mathrm{SN}_{2}$ nucleophilic substitution catalyzed by $\mathrm{K}_{2} \mathrm{CO}_{3}$, and 2-(4-acetyl-5-oxohexyl)-1H-isoindole-1,3(2H)-dione (1) was then used as reactant in the following Pabon reaction. With respect to acac, the presence of phthalimide chain shifted the tautomeric equilibrium of compound 1 in favor of the $\beta$-diketo form, 
as a consequence boron complexation was slow and the protection step needed longer time ( $2 \mathrm{~h}$ vs. $30 \mathrm{~min}$ ). The synthesized compounds, namely K3F, were isolated as yellow-orange powders by the general synthetic scheme reported in Figure 1.

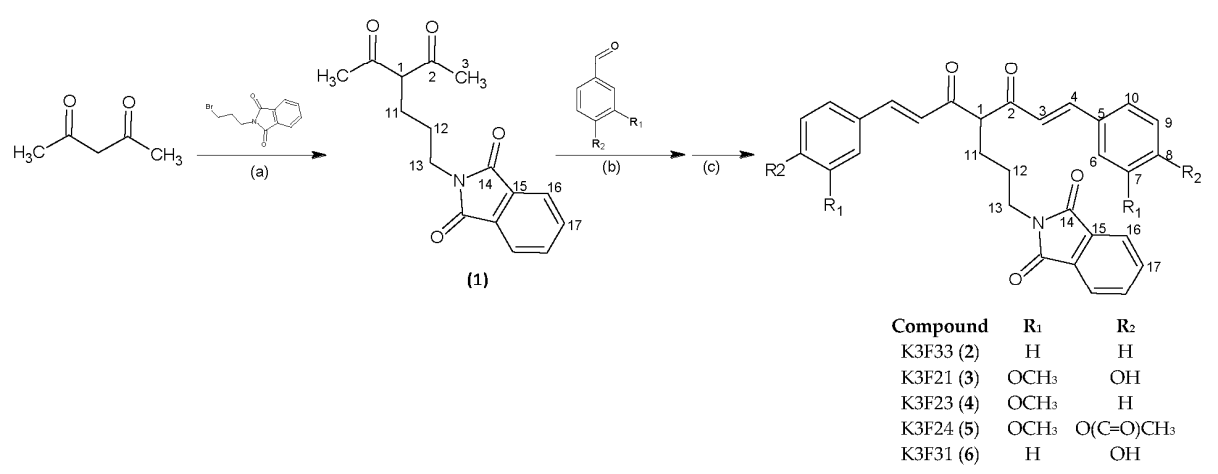

Figure 1. General scheme for the synthesis of phthalimide-based curcuminoids. (a) $\mathrm{K}_{2} \mathrm{CO}_{3} / \mathrm{KI}$, dry acetone, $80{ }^{\circ} \mathrm{C}, 24 \mathrm{~h}$; (b) $\mathrm{B}_{2} \mathrm{O}_{3}$, tributylborate, n-butylamine, $\mathrm{DMF}, 80^{\circ} \mathrm{C}, 6 \mathrm{~h}$; (c) $0.5 \mathrm{M} \mathrm{HCl}, 80{ }^{\circ} \mathrm{C}, 1 \mathrm{~h}$.

$\mathrm{pH}$-metric titrations were performed in order to assess K3F acidity and predict the most abundant species in physiological condition. On increasing $\mathrm{pH}$, a titration trend was observed for all the compounds, and, as reported for K3F21, the plot of $\mathrm{A}$ vs. $\mathrm{pH}$ at fixed $\lambda$ highlighted the presence of at least one equivalent point (Supplementary Figure S1). Overall protonation constants $\left(\beta_{\mathrm{HL}}\right)$ were calculated from spectrophotometric data and optimized by means of HypSpec software [15] (Supplementary Table S1). K3F23, K3F24 and K3F33 behaved as weak monoprotic acids, with a pKa value close to 8-8.50 associated to the keto-enol moiety. As for the other two ligands, namely K3F21 and K3F31, the acid-base equilibria were more complex in view of the polyprotic nature of the compounds, and three $\log \beta_{\text {LH }}$ values were calculated. Species distribution curves (Supplementary Figure S2) provided reliable prediction of neutral and charged forms as function of $\mathrm{pH}$, and consequently helped to envisage cell penetration and distribution in physiological conditions. For monoprotic acids K3F23, $\mathrm{K} 3 \mathrm{~F} 24$, and K3F33, the prevailing species at $\mathrm{pH} 7$ was the neutral one (HL). As for K3F21 and K3F31, they behaved as less weak acids, in fact at $\mathrm{pH} 758 \%$ of $\mathrm{K} 3 \mathrm{~F} 21$ and $65 \%$ of $\mathrm{K} 3 \mathrm{~F} 31$ were found in the mono-dissociated negatively charged form $\left(\mathrm{H}_{2} \mathrm{~L}^{-}\right)$, these percentages increased up to $74 \%$ and $86 \%$ respectively at $\mathrm{pH}$ 7.4. $\mathrm{K} 3 \mathrm{~F} 31$ resulted to be more dissociated than $\mathrm{K} 3 \mathrm{~F} 21$ at the same $\mathrm{pH}$, hence more acid. This outcome could be attributed to the stabilizing effect of the intramolecular hydrogen bond between the methoxyl and hydroxyl groups on the aromatic ring in the indissociated form of K3F21, which shifts the equilibrium in favor of the neutral species $\left(\mathrm{H}_{3} \mathrm{~L}\right)$.

The coupling of curcumin backbone with phtalimide moiety improved stability with respect to the lead molecule that degrades up to $40 \%$ within the first hour [23], in particular K3F33 was the most stable compound of the series, with a residual percentage close to $60 \%$ after $24 \mathrm{~h}$ (Figure 2A).

The phenolic derivatives K3F21 and K3F31 were tested for their radical scavenging ability by DPPH assay (Figure 2B). Both K3F21 and K3F31 exerted radical scavenging activity against DPPH radical, however K3F21 was more effective as suggested by $\mathrm{IC}_{50}$ values $(24 \mu \mathrm{M}$ vs. $120 \mu \mathrm{M})$. The intramolecular hydrogen bond between the phenolic hydrogen and the methoxyl oxygen seems to be a conditio sine qua non for the formation of a stable radical species. 
A

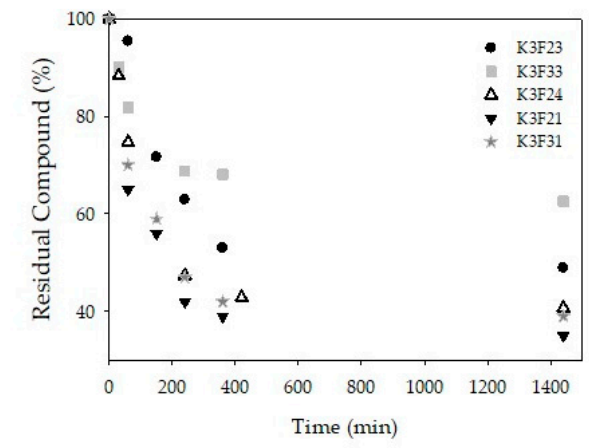

B

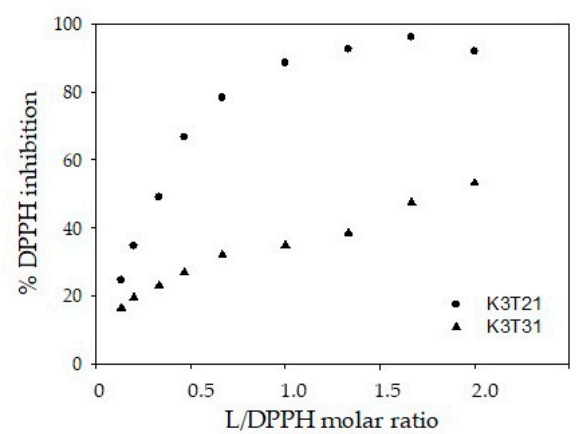

Figure 2. Stability and radical scavenging ability of $\mathrm{K} 3 \mathrm{~F}$ derivatives. (A) Residual \% of $\mathrm{K} 3 \mathrm{~F}$ compounds vs. time (PBS $0.01 \mathrm{M}, \mathrm{NaCl} 0.1 \mathrm{M}, \mathrm{pH}=7.4,37^{\circ} \mathrm{C}$ in darkness). Residual \% is calculated as $\mathrm{A}_{\mathrm{t}} \cdot 100 / \mathrm{A}_{0}$, where $A_{t}$ and $A_{0}$ stand for absorbance at $\lambda_{\max }$ at time $t$ and time zero, respectively. (B) Percentage of inhibition of free DPPH radical ([DPPH $]=60 \mu \mathrm{M})$ in the presence of $\mathrm{K} 3 \mathrm{~F}$ compounds at increasing concentrations. Compounds concentration is expressed as molar ratio (compound/DPPH).

\subsection{Phthalimide-Based Curcumin Derivatives Decrease Viability of Human Cancer Cells}

To investigate the potential anti-tumor activity of the new synthesized molecules, we tested their effect on the proliferation of cancer cell lines, in particular PC3 and DU145, two of the most representative in vitro models of $\mathrm{PCa}$, in which AR is not expressed. Dose-response assays were performed with K3F21, K3F23, K3F24, and K3F33 (Figure 3A,B) and GI50 values were determined as the concentration that causes $50 \%$ growth inhibition following $48 \mathrm{~h}$ of treatment (Figure $3 \mathrm{C}$ ). The comparison between curcumin and K3F-derivatives highlighted that the addition of phthalimide significantly enhances the anti-proliferative activity of K3F21 and K3F23 in PC3 and DU145 cells (Figure 3C). Similarly, we tested the activity of the compounds in another cancer cell line, the colon carcinoma HCT116 cells, in which the effect of curcumin has been largely investigated and characterized [24]. Also in these cells, K3F21 is the most active molecule compared to the other derivatives (Supplementary Figure S3A,B). 
A

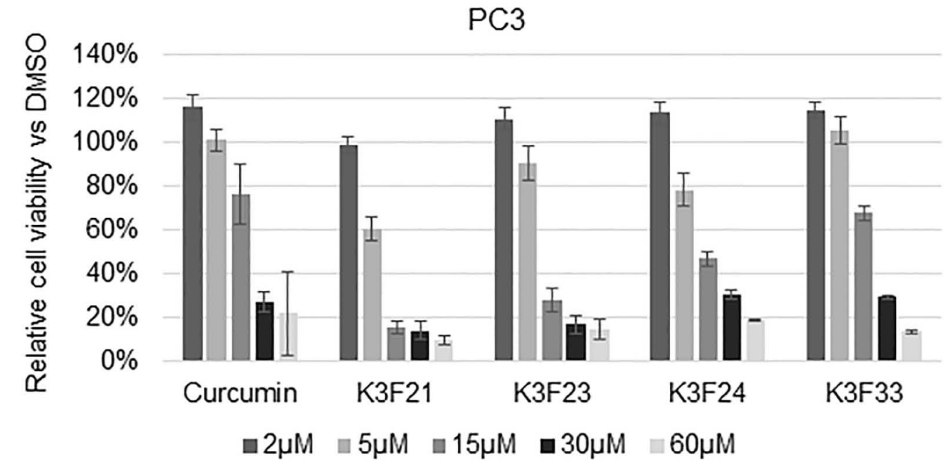

B

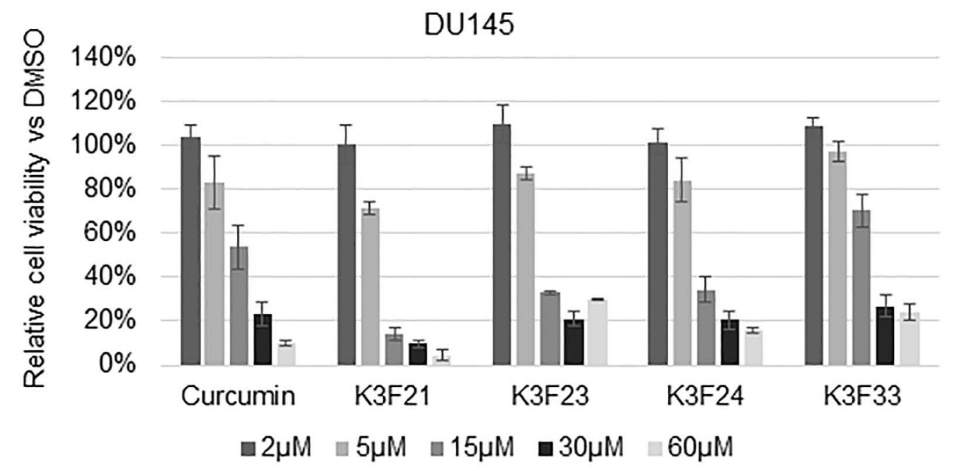

C

D

\begin{tabular}{|c|c|c|}
\hline PC3 & $\mathrm{Gl50}(\mathrm{\mu M})$ & SEM \\
\hline Curcumin & 21.0 & 2.4 \\
\hline K3F21 & 7.9 & 0.7 \\
\hline K3F23 & 12.4 & 1.2 \\
\hline K3F24 & 16.7 & 0.9 \\
\hline K3F33 & 21.8 & 0.7 \\
\hline
\end{tabular}

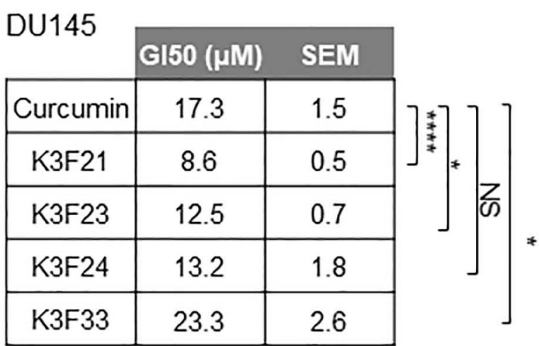

Figure 3. Dose-dependent effect of K3F-derivatives on PCa cells. Cell growth of PC3 (A) and DU145 (B) prostate cancer cells was assessed by MTT assays following $48 \mathrm{~h}$ treatment with the indicated molecules. Data are presented as relative cell viability (\%) of treated cells versus DMSO control cells, arbitrarily set at $100 \%$. The bars represent the mean of four independent experiments \pm SEM. GI50 values, SEM and statistical significance compared to curcumin have been indicated for PC3 (C) and DU145 (D). $p$ values ${ }^{*}<0.05, * * * * 0.0001, \mathrm{NS}=$ not significant.

To determine whether K3F-derivatives could have cytotoxic rather than cytostatic activity, we analyzed the distribution of the cells within the different phases of the cell cycle following the administration of the molecules at GI50 doses for $48 \mathrm{~h}$ (Figure 4 and Supplementary Figure S4A,B). In PC3 cells, curcumin administration resulted in an evident increase of the G2/M population, which raised from about 19\% in control cells (DMSO) to 37\% in treated cells. Similarly, K3F21, K3F23, K3F24, and $\mathrm{K} 3 \mathrm{~F} 33$ doubled the percentage of $\mathrm{G} 2 / \mathrm{M}$ cells, highlighting a cytostatic activity of the molecules. Only the administration of curcumin and K3F33 significantly increases SubG1 events, indicative of 
cell death (Figure 4A). As for DU145, curcumin mainly acts as a cytotoxic drug, as indicated by the significant increase of SubG1 events from 1.75\% to 5\% in control and treated cells, respectively. K3F24 and K3F33 showed the ability to arrest cell cycle progression, while K3F21 and K3F23 both arrested the G2/M progression and induced cell death (Figure 4B).

A

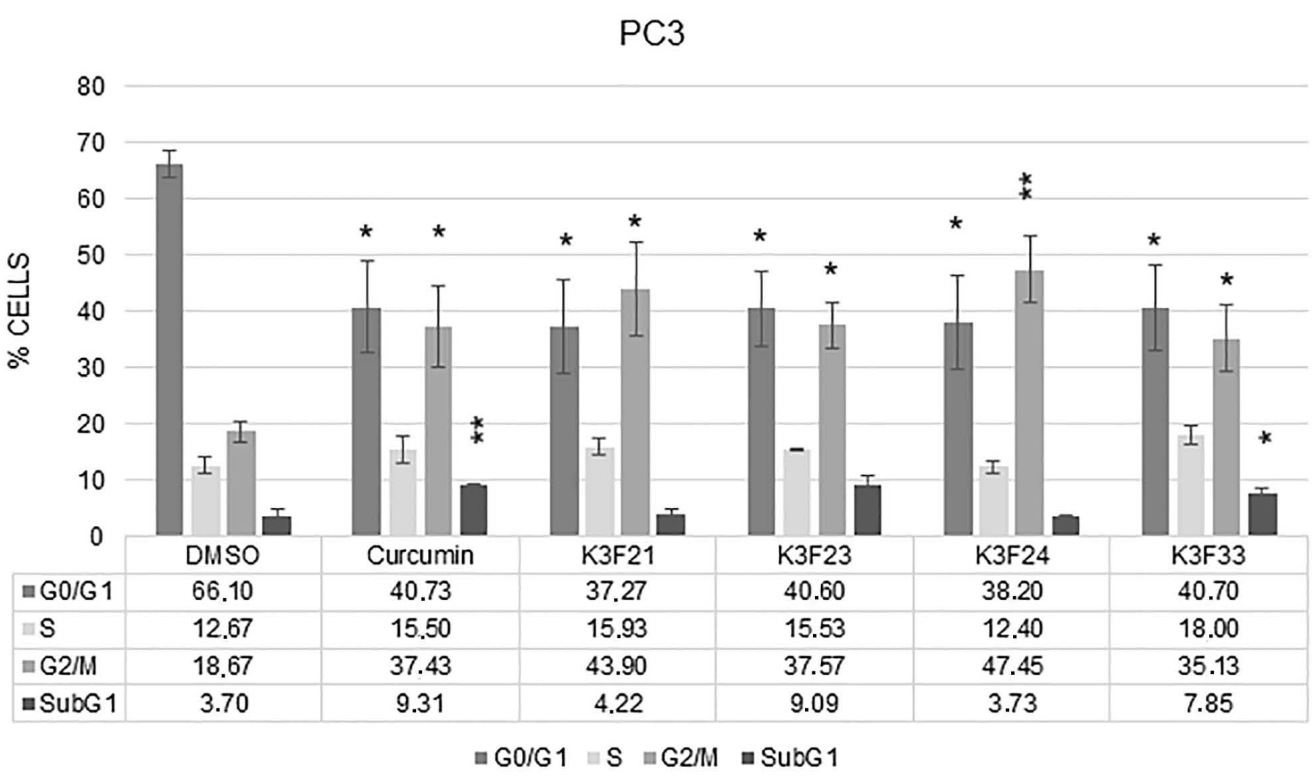

B

\section{DU145}

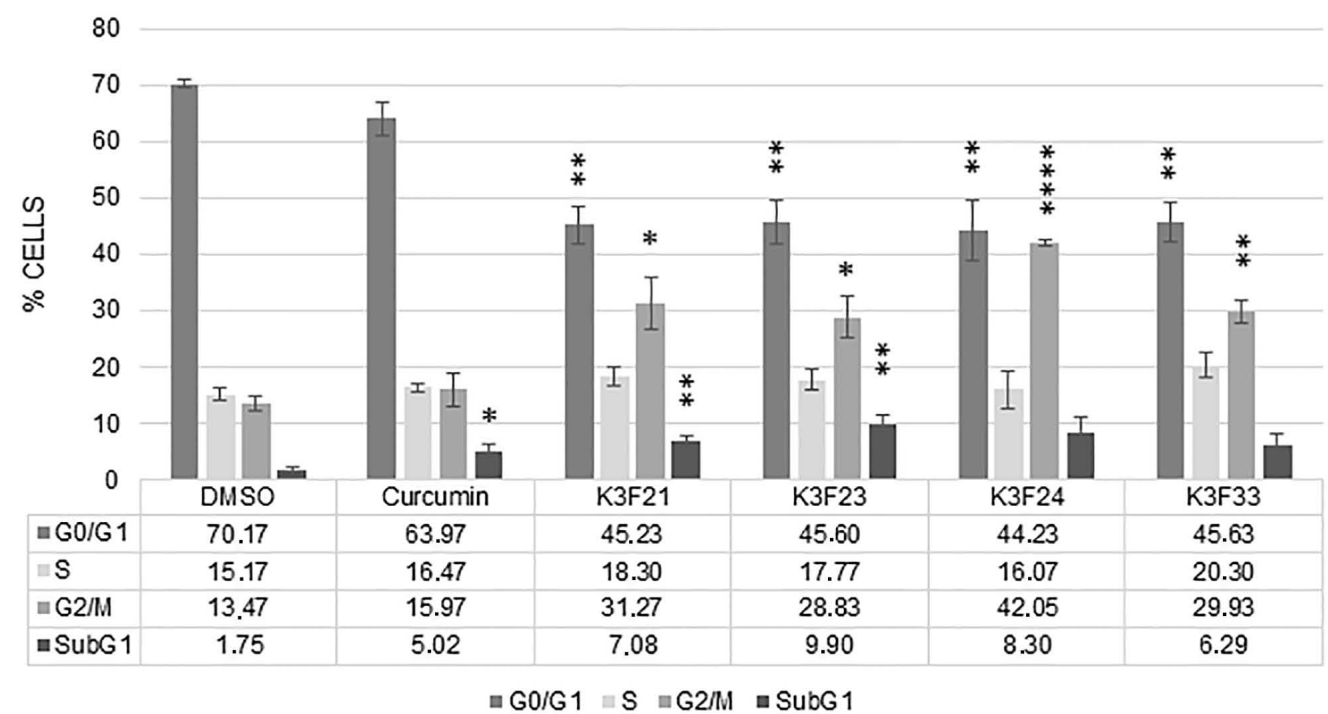

Figure 4. Effects on cell cycle progression of K3F derivatives. Cell distribution between cell cycle phases following administration for $48 \mathrm{~h}$ of DMSO, Curcumin or the indicated K3F-derivatives on PC3 (A) and DU145 (B) prostate cancer cells at GI50 concentrations. The bars represent the mean of three independent experiments \pm SEM. Representative images of cell cycle analysis are shown in Supplementary Figure S4. $p$ values refer to the comparison between K3F-derivatives and DMSO samples: ${ }^{*}<0.05,{ }^{* *}<0.01,{ }^{* * * *}<0.0001$. 
The semisynthetic taxane docetaxel (DTX), chemotherapeutic agent approved by FDA for its ability to prolong survival in patients with metastatic CRPC [25], was used as positive anti-proliferative compound. As expected, DTX administration at GI50 dose showed a high cytotoxic effect associated to a robust increase in SubG1 events (Supplementary Figure S4C,D).

K3F-derivatives were also tested in HCT116 cells: all the molecules induced a significant increase in SubG1 events (Supplementary Figure S3C).

Taking into consideration that all K3F-derivatives showed anti-proliferative effects, but K3F21 is the molecule with the lowest GI50 value in all the tested cell lines, we decided to further investigate its molecular activity as anti-cancer drug in PCa cells.

\subsection{K3F21 Administration Modulates the Transcription of Genes Involved in PCa Cell Growth}

The anti-proliferative and pro-apoptotic activity of curcumin on PCa cells was previously reported [10,26-28]. Among the mechanisms through which curcumin impacts on PCa proliferation, transcriptional modulation of genes controlling cell cycle progression and apoptosis has been described in vitro and in vivo (reviewed in [10]). We therefore decided to investigate the transcriptional effect of K3F21 administration on these processes in PC3 and DU145 cells, analyzing selected representative target genes. In both cell lines, we observed a general decrease, though not always significant, in the transcription of Cdc2, CyclinB1, CyclinB2, and CyclinD1 cell cycle genes in K3F21-treated cells compared to curcumin and control cells (Figure 5). The transcription of genes encoding CDK inhibitors p21 and p27 similarly increased following curcumin and K3F21 administration in PC3 cells, while they raised only after K3F21 treatment in DU145 cells. These results are consistent with cell cycle analysis (Figure 4), showing that curcumin and K3F21 similarly arrested cell cycle progression in PC3 cells, while only K3F21 induced a G2/M block in DU145 cells. The analysis of EGFR, linked to the proliferation of PCa cells, highlighted that its expression is reduced by K3F21 only in DU145 cells. Finally, we analyzed few apoptotic genes, such as the pro-apoptotic Noxa, Puma, and Bad, and the anti-apoptotic $B c l-2$ and $B c l-x l$ genes. While Noxa was induced by K3F21 as well as curcumin, Puma increased exclusively following K3F21 administration, in both PCa cells. As for anti-apoptotic genes, different transcriptional programs were activated in the two cell lines: $B c l-2$, but not $B c l-x l$, was weakly repressed by K3F21 in PC3, as opposed to DU145. 


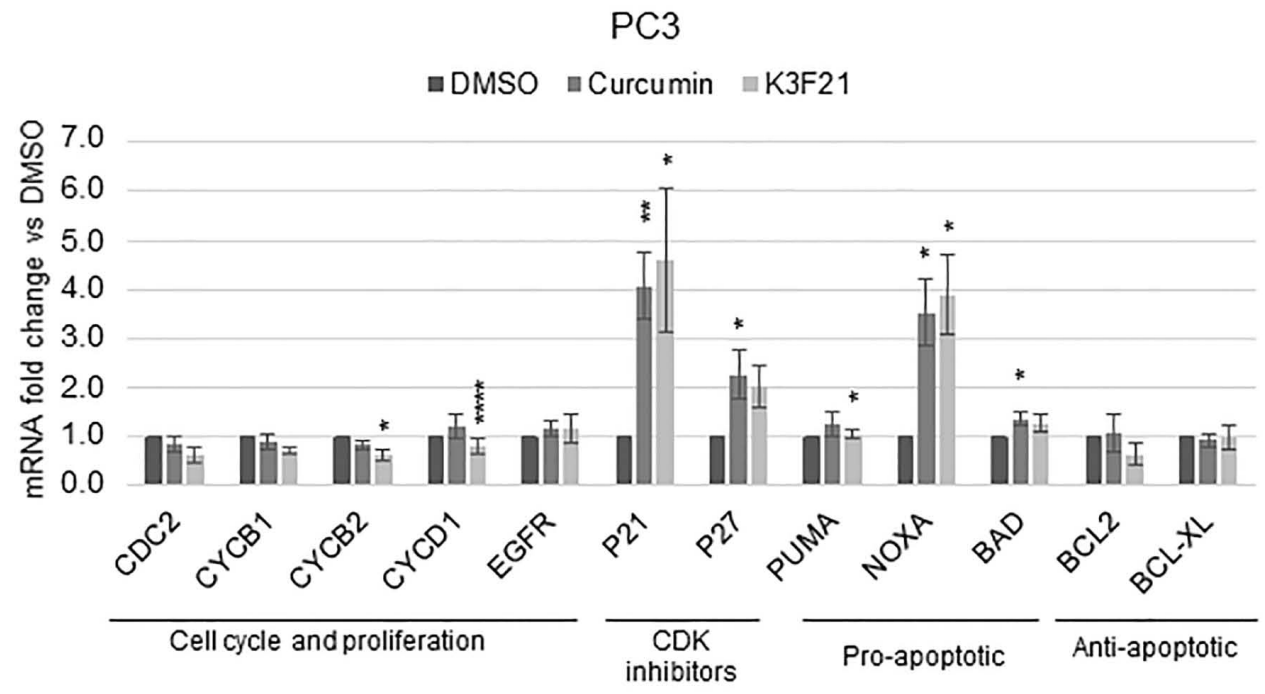

B

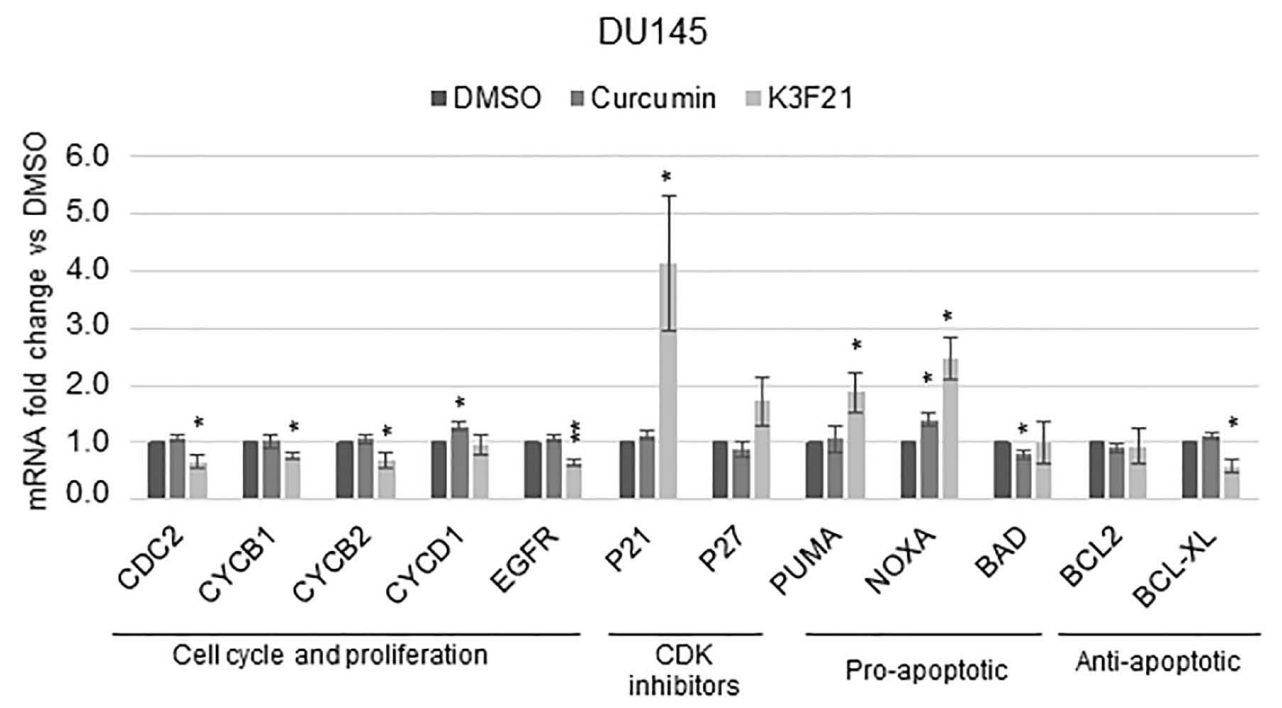

Figure 5. Effect of curcumin and K3F21 on gene transcription. RT-qPCR on PC3 (A) and DU145 (B) prostate cancer cells treated with DMSO, curcumin and K3F21 for $48 \mathrm{~h}$ at GI50 doses. Data are presented as relative transcript levels, normalized with RPL21 housekeeping gene, with DMSO levels arbitrarily set at 1 . The bars represent the means of three independent experiments \pm SEM. $p$ values refer to the comparison between curcumin and K3F21 with DMSO samples: ${ }^{*}<0.05, * *<0.01$, $* * * *<0.0001$.

\subsection{K3F21 Affects the Key Molecular Pathways Promoting PCa Progression}

Multiple intracellular signaling pathways implicated in PCa progression are modulated by anti-cancer drugs, as corroborated by the analysis of whole cellular extracts from DTX-treated PCa cells (Supplementary Figure S5). By western blot analysis, we determined whether K3F21 is able to inhibit the activation of receptor tyrosine kinase signaling (Figure 6A). 
Firstly, we studied the effect of K3F21 administration on PI3K/AKT pathway activation, significantly deregulated in PCa [29]. Both curcumin and K3F21 inhibited the phosphorylation of AKT in Ser473 and Thr308 in PC3 cells [30]. We were not able to detect AKT phosphorylation in DU145 cells, presumably due to the presence of the oncosuppressor PTEN that minimizes endogenous AKT activation [30]. Administration of chemotoxic drugs has been shown to induce ERK phosphorylation, and an inverse relation seems to link ERK and AKT activity in PCa [30-32]. Western blot analysis showed that both curcumin and K3F21 increased ERK1/2 phosphorylation in PC3 and, more evidently, in DU145 cells, likely as a consequence of reduced basal levels of PI3K/AKT activity [30].

Finally, p38 phosphorylation was investigated as important mechanism mediating cellular pro-inflammatory responses in PCa [10]. The administration of K3F21, but not curcumin, inhibited phospho-p38 expression in PC3, while no changes were observed in DU145 cells.

We also analyzed the effect of the molecules on the expression of $\gamma \mathrm{H} 2 \mathrm{AX}$, as a marker of DNA damage commonly activated by chemoterapeutic drugs (Figure 6B). While curcumin increased $\gamma \mathrm{H} 2 \mathrm{AX}$ in PC3 only, K3F21 triggered DNA damage in both PC3 and DU145 cells, indicating a genotoxic effect independent from the status of p53. Indeed, the oncosuppressor p53, involved in DNA damage response, is not expressed in PC 3 and mutated in its activity in DU145 cells. Moreover, the evaluation of PARP-1 cleavage corroborated the activation of apoptotic cell death following K3F21 administration only in DU145 cells, as already observed by cell cycle analysis (Figure 4).

A

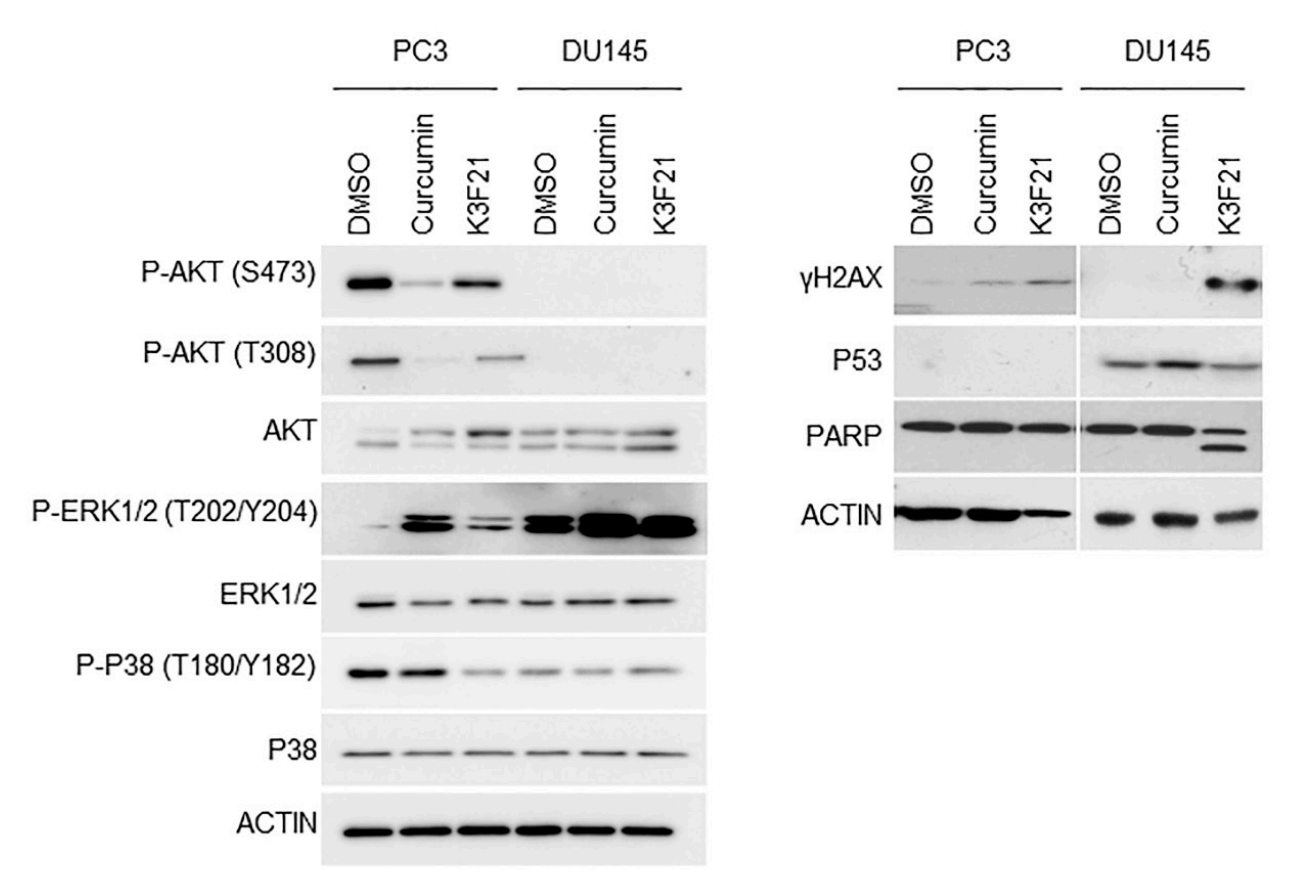

B

Figure 6. Effects of K3F21 on PCa promoting pathways. Total cellular lysates from PC3 and DU145 cells treated with DMSO, curcumin and K3F21 for $48 \mathrm{~h}$ at GI50 doses were analyzed by western blot with the indicated antibodies involved in receptor tyrosine kinase signaling (A) or DNA damage pathways (B). Actin was used as loading control.

\subsection{K3F21 Inhibits Metastatic Ability of PCa Cells to Migrate and Proliferate}

Increased cell motility of cancer cells, among which PCa cells, strongly impacts on their metastatic potential. We therefore tested whether K3F21 could decrease the migration ability of PC3 and DU145 cells, characterized by high metastatic potential. In vitro wound assays were performed and cell migration of curcumin and K3F21-treated cells was calculated as percentage of wound recovery compared to control cells. As shown in Figure 7, while DMSO-treated cells filled about 100\% of 
the wound area, K3F21 exerted inhibitory effects on the migratory capacity of PCa cells, similarly to curcumin. Interestingly, K3F21 showed more potent anti-migration activity compared to DTX, commonly used in anti-cancer clinical therapy.

A
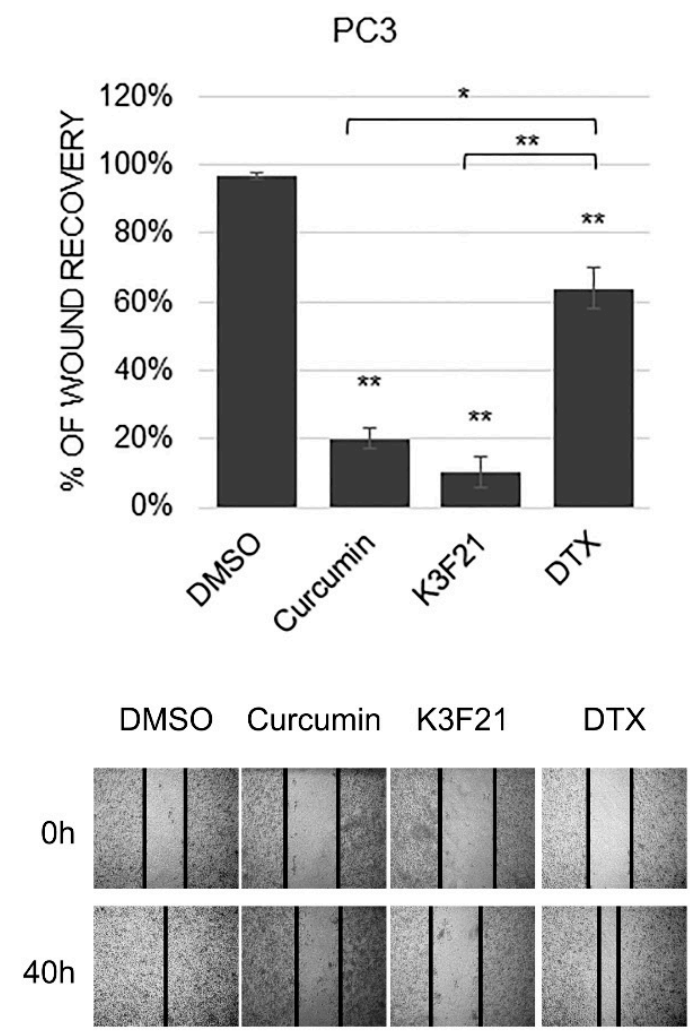

B DU145

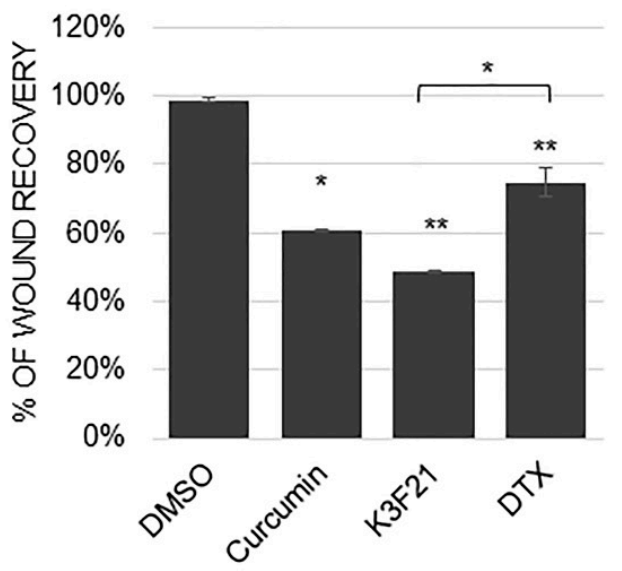

DMSO Curcumin K3F21 DTX

Oh

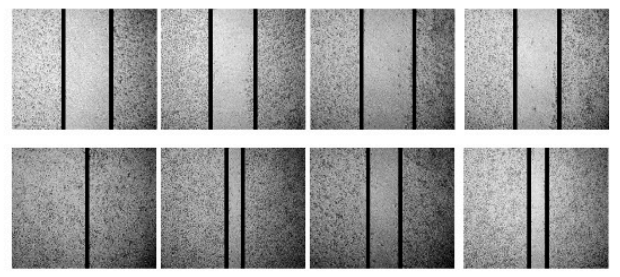

Figure 7. Inhibition of cell migration by curcumin, K3F21 and DTX. The percentage of wound recovery was assessed following DMSO, curcumin, K3F21 and DTX administration at GI50 doses in PC3 (A) and DU145 (B) after 40 and $16 \mathrm{~h}$, respectively. Representative images are shown in lower panels. $p$ values ${ }^{*}<0.05,{ }^{* *}<0.01$.

Next, we performed a clonogenic assay, based on the ability of a single cell to grow into a colony, to determine the effectiveness of the anti-proliferative activity of K3F21 to inhibit cell growth of PCa cells also in this condition. Plated PC 3 and DU145 cells were treated with different doses of curcumin and K3F21 and the number of colonies were counted following 7 or 10 days, respectively, and reported as percentage vs. DMSO control cells. K3F21 clearly inhibited cell growth when administered at lower concentrations than curcumin, in both cell lines (Figure 8A,B). Interestingly, despite the GI50 value of K3F21 in traditional 2D monolayer PC3 culture was established as about $10 \mu \mathrm{M}$, colony formation was quite completely abolished already at $5 \mu \mathrm{M}$, at least in PC 3 cells.

Finally, we investigated whether K3F21 was able to inhibit the proliferation of PCa cells when cultured in suspension within a semi-solid gel. The ability to grow in the absence of anchorage to the extracellular matrix (anchorage-independent condition) is one of the hallmarks of malignancy and is crucial in the tumor progression. The decrease in colony formation reached up to $95 \%$ following K3F21 treatment at 5 and $10 \mu \mathrm{M}$ in PC3 and DU145 cells, respectively (Figure 8C,D, Supplementary Figure S6). In PC3 cells, we observed enhanced anti-tumor activity of K3F21 compared to curcumin: similar effects were induced by curcumin when administered at 10 and $20 \mu \mathrm{M}$ compared to K3F21 $5 \mu \mathrm{M}$. 
A

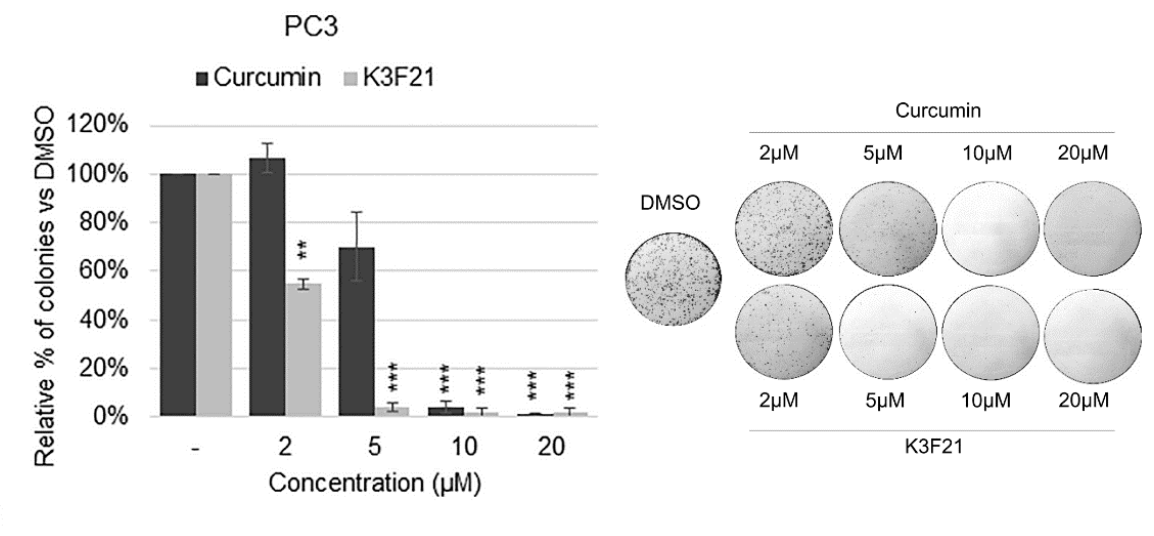

$\mathrm{B}$

DU145
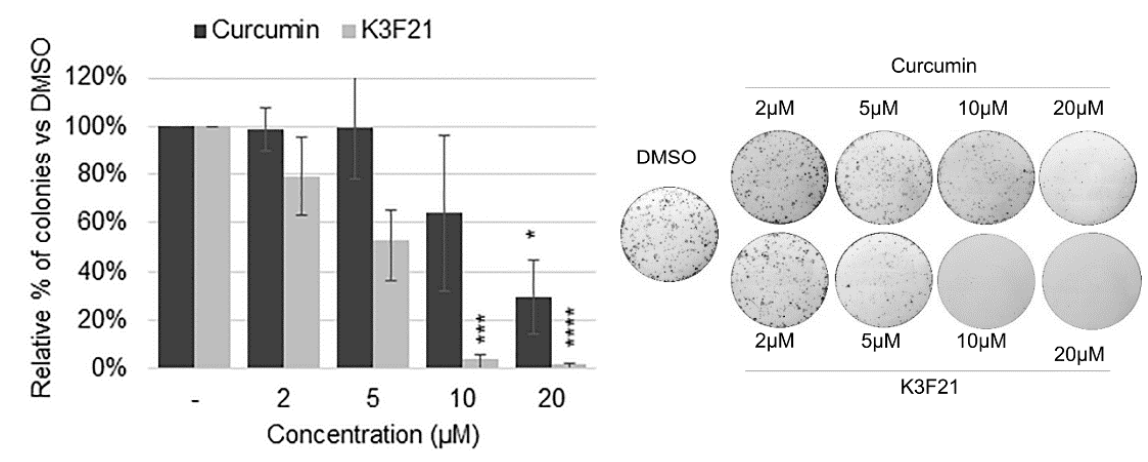

C
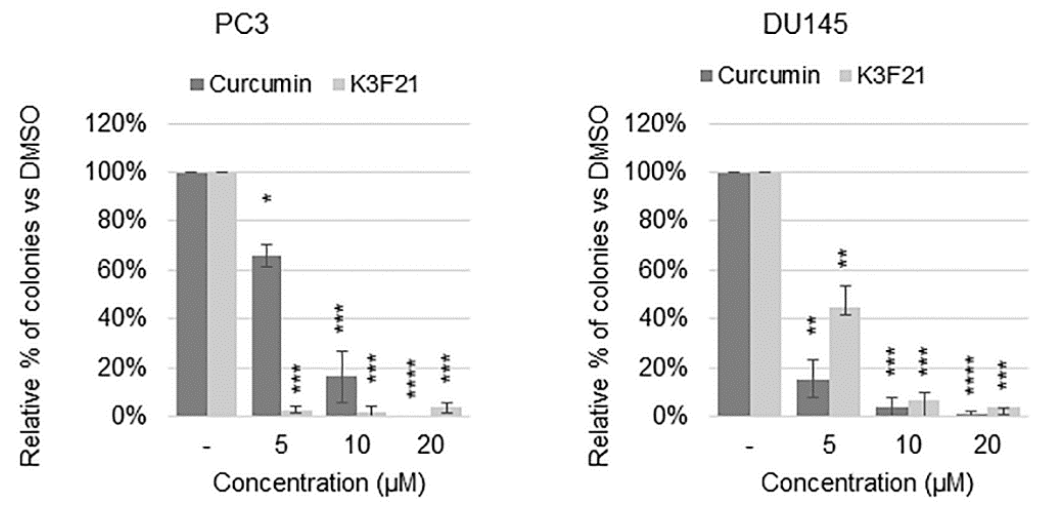

Figure 8. K3F21 inhibits colony formation of PCa cells. The number of colonies in PC3 and DU145 cells cultured in anchorage-dependent $(\mathbf{A}, \mathbf{B})$ or anchorage-independent conditions $(\mathbf{C}, \mathbf{D})$ in the presence of increasing doses of curcumin and K3F21 is reported as percentage versus DMSO treated cells, arbitrarily set at $100 \%$. Data are the mean of three independent experiments \pm SEM. P values refer to the comparison between curcumin and K3F21 with DMSO samples: ${ }^{*}<0.05,{ }^{* *}<0.01$, $* * *<0.001,{ }^{* * * *}<0.0001$. Representative images of anchorage-independent colony assay are shown in Supplementary Figure S6.

\subsection{K3F21 Enhances Anti-Tumor Activity of Docetaxel in DU145 Cells}

The combination of DTX with other anti-proliferative molecules has been proposed as a promising strategy for enhancing the sensitivity to chemotherapy in CRPC. Curcumin co-administration to DTX was shown to increase the anti-proliferative activity of the two molecules with respect to single treatments. In particular, their combination modulates the expression and activity of proteins commonly hyper-activated in PCa [33]. We therefore decided to investigate the effect of K3F21 
co-administration with DTX on PC3 and DU145 cells (Figure 9). Treatment with DTX resulted in a dose-dependent decrease in cell viability of PCa cells. In DU145 cells, co-administration of K3F21 and DTX 20nM for $48 \mathrm{~h}$ induced a significant decrease in cell viability compared to independent treatments with DTX or K3F21. The determination of the Combination Index (CI) [34] revealed a slight synergism $(\mathrm{CI}=0.8)$ between the drugs with a DTX drug reduction index (DRI) of 2.9, hinting that concurrent administration with K3F21 could allow an effective reduction of DTX dose. Differently, none of the evaluated K3F21/DTX combinations affected cell growth when compared simultaneously to both DTX and K3F21 single administration in PC3 cells.

A

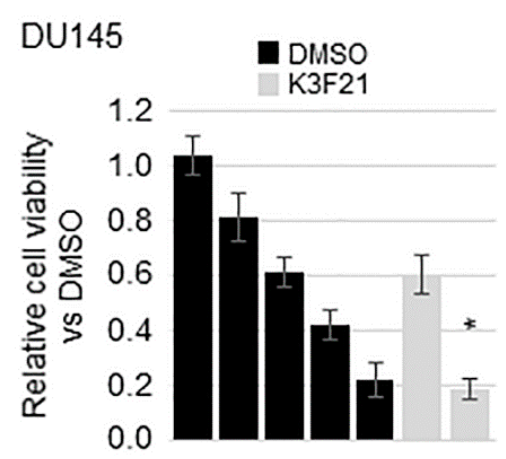

DOCETAXEL (nM) 055102060020
$\mathrm{B}$

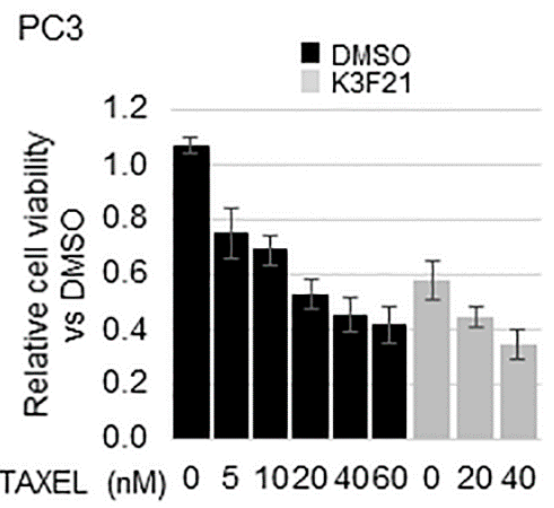

Figure 9. Combinatorial effect of K3F21 with docetaxel on PCa cells viability. The effect of docetaxel or docetaxel/K3F21 co-administration determined by MTT assay in DU145 (A) and PC3 (B) is indicated relatively to DMSO treatment, arbitrarily set at $1 .{ }^{*}$ indicates synergism $(\mathrm{CI}<1)$.

\section{Discussion}

In preclinical models, thalidomide and its derivatives have shown growth inhibition and enhanced susceptibility to apoptosis of tumor cells [35]. However, in terms of the achieved response rates, i.e., the percentage of patients whose cancer shrinks or disappears after treatment, thalidomide showed mild activity towards CRPC. Phase II clinical trial showed that about $30-40 \%$ of patients with metastatic CRPC had a decline in PSA of $\geq 40 \%$, associated with an improvement of clinical symptoms, following thalidomide treatment [36,37].

As regards curcumin, several studies have shown its potential therapeutic effects on PCa cells survival, both in vitro and in vivo $[16,26,27,38]$. In particular, the activity of curcumin has been well described on PC3 cells, accepted in vitro model of highly aggressive prostate cancer [16,39]. Nevertheless, the growth suppressive activity and bioavailability of curcumin in humans showed limitations for its use as an effective therapeutic agent in cancer. Therefore, the conjugation of phtalimide with curcumin and its derivatives could represent a successful strategy to develop new multi-target derivatives to defeat PCa. In addition, as previously observed for other $\beta$-diketo substituted curcuminoids [22], the presence of a bulky substituent in $\alpha$ position to the keto-enol moiety shifts the equilibrium towards the diketo form, improving stability and potentially bioavailability. K3F33, K3F23, and K3F24 show an acid-base behavior similar to curcumin, with a typical $\mathrm{pK}_{\mathrm{a}}$ value ranging from 8 to 8.5 that can be attributed to the dissociation of enol proton. Differently, as suggested for other curcuminoids [40], the low value of the first $\mathrm{pK}_{\mathrm{a}}$ for K3F21 and K3F31 could be reasonably attributed to the phenol group, which acidity is decreased by the conjugated keto-enol group in para position. For these compounds, the second $\mathrm{pK}_{\mathrm{a}}$ is due to the keto-enol moiety, and the last one to the second phenolic group.

This study reports on the synthesis, chemical and biological characterization of the phthalimide-based curcuminoids as new potential therapeutic molecules in PCa. Chemical characterization and in vitro data 
on tumor cell lines identified K3F21 as the most attracting molecule for further cellular and molecular characterization of its anti-proliferative activity. In fact, K3F21 is a weak acid that is indissociated in physiological condition, hence present in its neutral form. The high lipophilicity (data not shown) together with its low molecular mass allow to predict high bioavailability. The presence of phtalimide moiety stabilizes the diketo tautomer, improving on one hand pharmacokinetics with respect to curcumin and maintaining similar radical scavenging activity on the other. K3F21 shows higher efficacy in terms of growth inhibitory activity (GI50) compared to curcumin, not only in PCa cells but also in human colon adenocarcinoma cells. Although K3F21 has a similar GI50 concentration on PC3 and DU145 cells, it exerts different anti-proliferative effects in the two cell lines. While its administration to PC3 significantly increases the G2/M population, without inducing cell death, DU145 treated cells shows both G2/M cell cycle arrest and apoptosis (Figure 4). The analysis by western blot of cleaved-PARP1 suggests the activation of a caspase-mediated cell death (Figure 6).

PC3 and DU145 cells are characterized by non-luminal-like phenotypes and are representative of aggressive disease, with similarity in overall gene expression [41]. Indeed, the analysis of single gene transcription, performed by RT-qPCR, highlighted the activation of quite similar transcriptional programs by curcumin and K3F21 in the two cell lines (Figure 5). Despite this, we should consider that PC3 and DU145 cells differ in the status of the $p 53$ gene, which encodes for a transcription factor involved in the response to cellular stresses, DNA damage, and cytotoxic drugs. During PCa progression, epithelial cells acquire different mutations in key genes controlling cell proliferation and cell survival, among which p53 [42]. In particular, mutations that give rise to mutant gain of function (GOF) or dominant negative (DN) p53 allow the tumor to survive anticancer therapies [43]. The administration of DNA damaging agents to mutant p53 cells may potentially further increase cancer progression: mutant p53 cells usually escape cell cycle arrest following DNA damage, which eventually triggers the acquisition of more mutations allowing cancer cell survival. While PC 3 cells are p53-null, therefore they do not express p53 at the protein level, DU145 cells express mutant DN p53 (P223L/V274F) [44,45]. K3F21 efficiently inhibits cell proliferation in DU145 as well as in PC3 cells when cultured in normal 2D conditions. Differently, curcumin and K3F21 activities on cell migration and colony formation in anchorage-independent condition, key futures of cancer cells, highlighted the increased sensitivity of PC3 cells vs. DU145 cells towards curcumin and K3F21 (Figure 8). It is interesting to note that in $3 \mathrm{D}$ culturing conditions, that better mimic the physiological in vivo tumor growth condition, K3F21 is more active than in normal 2D monolayer culture conditions.

Finally, we should also consider the status of the PTEN/PI3K/AKT axis in the examined cells. PTEN is one of the anti-apoptotic genes frequently mutated in PCa: while PC3 are PTEN-negative, DU145 cells possess the functional protein. This difference plays a great role in the activation of the PI3K/AKT and ERK pathways: PTEN expression in DU145 cells minimizes aberrant activation of $\mathrm{PI} 3 \mathrm{~K} / \mathrm{AKT}$, which is sufficient for upregulation of ERK phosphorylation. ERK activation seems to be necessary for drug-induced death and its inactivation has been identified as a hallmark of advanced PCa $[31,32,46]$. Consistent with these published data, our western blot analysis highlighted that K3F21-induced inhibition of AKT phosphorylation is associated with increased ERK activation in both PC3 and DU145 cells (Figure 6).

Treatment of PCa cells with DTX inhibits their proliferation and activates apoptosis. Since curcumin has been recently shown to increase the efficacy of DTX treatment in PCa [33], we decided to investigate the effect of K3F21 and DTX combination. In DU145 only, we were able to quantitatively determine synergism with $\mathrm{CI}<1$ between the two molecules. Moreover, the favorable DTX dose-reduction index (DRI) suggested the promising potentiality of K3F21 as a therapeutic adjunct with DTX in the treatment of PCa. Further studies will help to elucidate why this effect is observed only in DU145 and not in PC3 cells.

Overall, our results indicate that K3F21 exhibits similar or more potent activity than curcumin in the inhibition of prostate cancer cell growth and migration, as well as in the modulation of key 
molecular pathways involved in tumor progression and survival. These results open the opportunity to develop K3F21 molecule as a new therapeutic drug in aggressive PCa tumors.

\section{Materials and Methods}

\subsection{General Procedures and Chemicals}

Elemental analysis was performed on Thermo ScientificTM FLASH 2000 organic elemental analyzer. The percentage of $\mathrm{C}, \mathrm{H}$, and $\mathrm{N}$ were experimentally calculated. Liquid chromatography/mass spectrometry (LC/MS) was performed on Agilent 6300 Ion Trap LC/MS System equipped with an electrospray ionization (ESI) interface. The compounds were separated using Agilent Zorbax SB C18 30 $\times 2.1 \mathrm{~mm}, 3.5 \mu \mathrm{m}$. Samples were prepared in $\mathrm{MeOH}$ and diluted to $10 \mathrm{ppm}$ in MilliQ water; blank was MilliQ water. Eluent phase: pump $\mathrm{A}_{2} \mathrm{O}$ (formic acid 1\%), pump B ACN (formic acid 1\%), gradient: $10 \%$ of $B$ for $1 \mathrm{~min}, 10-100 \%$ of $B$ for $5 \mathrm{~min}$, then $100 \%$ of $B$ for 4 minutes, flux $0.3 \mathrm{~mL} / \mathrm{min}$, injection volume $10 \mu \mathrm{L}$. The ion spectra were obtained in positive mode, using a scan range between 100 and $1500 \mathrm{~m} / \mathrm{z}$. High-purity nitrogen was used as nebulizer and drying gas (flow rate $10 \mathrm{~L} / \mathrm{min}, 350{ }^{\circ} \mathrm{C}$ ). The nebulizer gas pressure was $32 \mathrm{psi}$ and the capillary voltage was $3.5 \mathrm{kV}$. All reagent grade chemicals were purchased from Sigma-Aldrich (St. Louis, MO, USA) and used without further purification unless otherwise specified. NMR spectra were recorded on a Bruker FT-NMR AVANCE III HD $600 \mathrm{MHz}$ spectrometer with $5 \mathrm{~mm}$ CryoProbe BBO H\&F at $298 \mathrm{~K}$. Nominal frequencies were $600.13 \mathrm{MHz}$ for ${ }^{1} \mathrm{H}$ and $150.9 \mathrm{MHz}$ for ${ }^{13} \mathrm{C}$. For each sample, $\sim 5 \mathrm{mg}$ were weighed and diluted up to $0.6 \mathrm{~mL}$ with the proper deuterated solvent into $5 \mathrm{~mm}$ NMR tube. $90^{\circ}$ pulse was calibrated for each sample and standard NMR parameters were used to achieve quantitative results (relaxation delay $10 \mathrm{~s}$ ). Proton and carbon chemical shifts are given in parts per million (ppm) vs. external TMS, and were determined by reference to the solvent residual signals. Typical 2D homo- and hetero-nuclear techniques were used for assignment, i.e., ${ }^{1} \mathrm{H},{ }^{1} \mathrm{H}-\mathrm{COSY},{ }^{1} \mathrm{H},{ }^{13} \mathrm{C}-\mathrm{HSQC},{ }^{1} \mathrm{H},{ }^{13} \mathrm{C}-\mathrm{HMBC}$. The purity of all final compounds was determined to be at least $95 \%$ pure by a combination of LC-MS, NMR, and combustion analysis.

\subsection{Synthesis}

2-(4-acetyl-5-oxohexyl)-1H-isoindole-1,3(2H)-dione (1), (2-((4Z,6E)-5-hydroxy-7-(4-hydroxy-3methoxyphenyl)-4-((E)-3-(4-hydroxy-3-ethoxyphenyl) acryloyl) hepta-4,6-dien-1-yl)isoindoline-1,3-dione (K3F21) and 2-((4Z,6E)-4-cinnamoyl-5-hydroxy-7-phenylhepta-4,6-dien-1-yl)isoindoline-1,3-dione (K3F33) were synthesized and characterized as previously reported by the authors [47]. The same procedure was applied for the synthesis of K3F23, K3F31 and K3F24 that are here completely characterized.

(2-((4Z,6E)-5-hydroxy-7-(3-methoxyphenyl)-4-((E)-3-(4-hydroxy-3-ethoxyphenyl) acryloyl) hepta-4, 6-dien-1-yl)isoindoline-1,3-dione (K3F23). Yellow powder, yield 30\%. Elemental analysis for $\mathrm{C}_{32} \mathrm{H}_{29} \mathrm{NO}_{6}$ ( $\left.523.58 \mathrm{~g} / \mathrm{mol}\right)$ : calc. C $73.41 \% \mathrm{H}, 5.58 \%$, N 2.69\%; found: C 73.62\%, H 5.62\%, N 2.60\%. LC-MS (ESI): m/z $524.6[\mathrm{M}+\mathrm{H}]^{+} .{ }^{1} \mathrm{H}$ NMR (MeOD- $\left.d_{4}\right) \delta$ keto-enol form: $7.19\left(\mathrm{H}-3, \mathrm{~d}\left({ }^{3} \mathrm{~J}_{\mathrm{HH}} 15.3\right), 2 \mathrm{H}\right)$, $7.70\left(\mathrm{H}-4, \mathrm{~d}\left({ }^{3} \mathrm{~J}_{\mathrm{HH}} 15.3\right), 2 \mathrm{H}\right), 7.21\left(\mathrm{H}-6, \mathrm{~d}\left({ }^{3} \mathrm{~J}_{\mathrm{HH}} 8 \mathrm{~Hz}\right), 2 \mathrm{H}\right), 7.00\left(\mathrm{H}-8, \mathrm{dd},\left({ }^{3} \mathrm{~J}_{\mathrm{HH}} 8 \mathrm{~Hz} ;{ }^{4} \mathrm{~J}_{\mathrm{HH}} 2 \mathrm{~Hz}\right) 2 \mathrm{H}\right)$, $7.20(\mathrm{H}-9, \mathrm{~m}, 2 \mathrm{H}), 7.31$ (H-10, m, 2H), $2.71\left(\mathrm{H}-11, \mathrm{t}\left({ }^{3} \mathrm{~J}_{\mathrm{HH}} 7 \mathrm{~Hz}\right), 2 \mathrm{H}\right), 1.98(\mathrm{H}-12, \mathrm{~m}, 2 \mathrm{H}), 3.86(\mathrm{H}-13, \mathrm{t}$ (broad), 2H), 7.89 (H-16, m, 2H), $7.82(\mathrm{H}-17, \mathrm{~m}, 2 \mathrm{H}) .{ }^{13} \mathrm{C}$ NMR (MeOD-d 4 ) $\delta 110.6(\mathrm{C}-1), 183.2(\mathrm{C}-2)$, 119.4 (C-3), 142.0 (C-4), 134.2 (C-5), 112.6 (C-6), 160.1 (C-7), 116.7 (C-8), 129.8 (C-9), 120.2 (C-10) 23.7 (C-11), 31.6 (C-12), 38.3 (C-13), 168.6 (C-14), 134.8 (C-15), 123.4 (C-16), 134.7 (C-17).

(2-((4Z,6E)-5-hydroxy-7-(4-acetyl-3-methoxyphenyl)-4-((E)-3-(4-hydroxy-3-ethoxyphenyl) acryloyl) hepta-4,6-dien-1-yl)isoindoline-1,3-dione (K3F24). Light orange powder, $45 \%$ yield. Elemental analysis for $\mathrm{C}_{36} \mathrm{H}_{33} \mathrm{NO}_{10}$ : calc. C $67.60 \%, \mathrm{H} 5.20 \%, \mathrm{~N} 2.19 \%$; found $\mathrm{C} 67.25 \%, \mathrm{H} 5.35 \%, \mathrm{~N}$ 2.15\%. LC-MS-IT m/z $640.8(\mathrm{M}+\mathrm{H})+.{ }^{1} \mathrm{H}$ NMR $\left(\mathrm{CDCl}_{3}\right): 7.02\left(\mathrm{H}-3, \mathrm{~d}\left({ }^{3} \mathrm{~J}_{\mathrm{HH}} 15.6 \mathrm{~Hz}\right), 2 \mathrm{H}\right), 7.76(\mathrm{H}-4, \mathrm{~d}$ $\left.\left({ }^{3} \mathrm{~J}_{\mathrm{HH}} 15.6 \mathrm{~Hz}\right), 2 \mathrm{H}\right), 7.24\left(\mathrm{H}-6, \mathrm{~d}\left({ }^{3} \mathrm{~J}_{\mathrm{HH}} 7.8 \mathrm{~Hz}\right), 2 \mathrm{H}\right), 7.10\left(\mathrm{H}-9, \mathrm{~d}\left({ }^{3} \mathrm{~J}_{\mathrm{HH}} 7.8 \mathrm{~Hz}\right), 2 \mathrm{H}\right), 7.21(\mathrm{H}-10, \mathrm{dd}$ $\left.\left({ }^{3} \mathrm{~J}_{\mathrm{HH}} 7.8 \mathrm{~Hz},{ }^{4} \mathrm{~J}_{\mathrm{HH}} 3 \mathrm{~Hz}\right), 2 \mathrm{H}\right), 2.65\left(\mathrm{H}-11, \mathrm{t}\left({ }^{3} \mathrm{~J}_{\mathrm{HH}} 7 \mathrm{~Hz}\right), 2 \mathrm{H}\right), 2.05(\mathrm{H}-12, \mathrm{~m}, 2 \mathrm{H}), 3.89(\mathrm{H}-13, \mathrm{t}$ (broad), 2H), $7.86(\mathrm{H}-16, \mathrm{~m}, 2 \mathrm{H}), 7.80(\mathrm{H}-17, \mathrm{~m}, 2 \mathrm{H}) .{ }^{13} \mathrm{C} \mathrm{NMR}\left(\mathrm{CDCl}_{3}\right) \delta$ keto-enol form: $110.5(\mathrm{C}-1), 183.4$ 
(C-2), 120.4 (C-3), 141.6 (C-4), 134.2 (C-5), 111.9 (C-6), 151.4 (C-7), 141.9 (C-8), 121.2 (C-9), 123.2 (C-10) 23.9 (C-11), 31.5 (C-12), 38.2 (C-13), 168.7 (C-14), 134.8 (C-15), 123.4 (C-16), 134.7 (C-17).

(2-((4Z,6E)-5-hydroxy-7-(4-hydroxyphenyl)-4-((E)-3-(4-hydroxy-3-ethoxyphenyl) acryloyl) hepta-4,6-dien-1-yl)isoindoline-1,3-dione (K3F31) Orange powder, $40 \%$ yield. Elemental analysis for $\mathrm{C}_{30} \mathrm{H}_{25} \mathrm{NO}_{6}$ : calc. C 72.72\%, H 5.09\%, N 2.83\%) C 73.60\%, H 5.21\%, N 2.75\%. LC-MS-IT m/z 496.6 (M + $\mathrm{H})^{+} .{ }^{1} \mathrm{H}$ NMR (DMSO- $\left.d_{6}\right) \delta 7.00\left(\mathrm{H}-3, \mathrm{~d}\left({ }^{3} \mathrm{~J}_{\mathrm{HH}} 15.9 \mathrm{~Hz}\right), 2 \mathrm{H}\right), 7.58\left(\mathrm{H}-4, \mathrm{~d}\left({ }^{3} \mathrm{~J}_{\mathrm{HH}} 15.9 \mathrm{~Hz}\right), 2 \mathrm{H}\right), 7.54$ $\left(\mathrm{H}-6 / \mathrm{H}-10, \mathrm{~d}\left({ }^{3} \mathrm{~J}_{\mathrm{HH}} 8 \mathrm{~Hz}\right), 4 \mathrm{H}\right), 6.79\left(\mathrm{H}-7 / \mathrm{H}-9, \mathrm{~d}\left({ }^{3} \mathrm{~J}_{\mathrm{HH}} 8 \mathrm{~Hz}\right), 4 \mathrm{H}\right), 2.65\left(\mathrm{H}-11, \mathrm{t}\left({ }^{3} \mathrm{~J}_{\mathrm{HH}} 7 \mathrm{~Hz}\right), 2 \mathrm{H}\right), 1.83$ (H-12, m, 2H), 3.77 (H-13, t (broad), 2H), $7.88(\mathrm{H}-16, \mathrm{~m}, 2 \mathrm{H}), 7.85$ (H-17, m, 2H). ${ }^{13} \mathrm{C}$ NMR (DMSO- $\left.d_{6}\right) \delta$ keto-enol form: 110.8 (C-1), 183.3 (C-2), 117.4 (C-3), 142.1 (C-4), 126.7 (C-5), 131.1 (C-6/C-10), 116.3 (C-7/C-9), 160.4 (C-8), 22.8 (C-11), 26.1 (C-12), 37.6 (C-13), 168.7 (C-14), 134.8 (C-15), 123.4 (C-16), 134.7 (C-17).

\subsection{Acid-Base Behavior and Stability in Physiological Conditions}

UV-vis spectrophotometric measurements were performed using Jasco V-570 spectrophotometer at $25.0 \pm 0.1^{\circ} \mathrm{C}$ in the $200-600 \mathrm{~nm}$ spectral range employing $1 \mathrm{~cm}$ quartz cells. Owing to the poor water solubility of the compounds, a methanol mother solution $\left(5 \times 10^{-3} \mathrm{M}\right)$ was diluted in water in order to give $50 \mu \mathrm{M}$ solutions used for $\mathrm{pH}$-metric titrations. The $\mathrm{pH}$ value was varied by adding small amounts of concentrated $\mathrm{NaOH}$ or $\mathrm{HCl}, 25$ points in the $\mathrm{pH}$ range 3-10. A constant ionic strength of $0.1 \mathrm{M}\left(\mathrm{NaNO}_{3}\right)$ was maintained in all the experiments. Each titration was performed at least three times. The overall protonation constants $\left(\log \beta_{\mathrm{LH}}\right)$ were evaluated from spectrophotometric data using the software HypSpec [48].

Kinetic stability studies were performed at $37^{\circ} \mathrm{C}$ in darkness, the change in absorbance in the 200-600 $\mathrm{nm}$ range over an overall period of $8 \mathrm{~h}$ was estimated for all the K3F samples by UV-vis spectroscopy. $100 \mu \mathrm{M}$ solutions of the ligands were prepared in $0.1 \mathrm{M}$ Tris- $\mathrm{HCl}$ buffer (pH 7.4) with constant ionic strength $\left(0.1 \mathrm{M} \mathrm{NaNO}_{3}\right)$. Spectra were recorded every $30 \mathrm{~min}$. All profiles were linearized by hyperbolic function (Equation (1)), which represents an empirical model that well describes drug decomposition or release [49].

$$
\mathrm{t} / \mathrm{f}_{\%}=\mathrm{at}+\mathrm{b}
$$

where $f_{\%}$ is the fraction of residual compound at time $t$ ( $\mathrm{min}$ ) expressed as percentage referred to starting concentration at time zero.

\subsection{Antioxidant Activity (DPPH Assay)}

The antioxidant activity of the compounds was evaluated in terms of hydrogen donating or radical scavenging ability, using the stable DPPH radical (1,1-diphenyl-2-picrylhydrazyl radical). A variable amount $(15,30,45,75,105$, and $150 \mu \mathrm{L})$ of a methanol solution $(1.2 \mathrm{mM})$ of each compound was placed in a cuvette, and $3 \mathrm{~mL}$ of a $60 \mu \mathrm{M}$ methanol solution of DPPH was added. Absorbance measurements were initiated immediately. The decrease in absorbance at $517 \mathrm{~nm}$ was monitored every minute up to $5^{\prime}$, then every $5^{\prime}$ up to $30^{\prime}$ and every $30^{\prime}$ until reaction reaches completion and absorbance stabilizes attaining a plateau after $120^{\prime}$. Methanol was used to zero the spectrophotometer. The absorbance of the DPPH radical without K3F compound, i.e., the control, was measured daily, and concentration was calculated applying Equation (2) [50]

$$
\left[\mathrm{DPPH}^{\cdot}\right]=\frac{\mathrm{A}-1.006}{10970}
$$

The percentage of inhibition (\%In) of the DPPH radical by each sample was calculated according to the formula

$$
\% \text { In }=\frac{\mathrm{A}_{0}-\mathrm{A}_{\mathrm{t}}}{\mathrm{A}_{0}} \times 100
$$


where $A_{0}$ represents the absorbance of the control (DPPH radical) at time 0 , while $A_{t}$ refers to the absorbance of the mixture DPPH/antioxidant at time $t(120 \mathrm{~min})$. Values of absorbance were corrected taking into account volume dilution and all determinations were performed in triplicate.

\subsection{Cell Lines and Treatments}

Human prostate cancer PC3 cells (CRL 1435, ATCC, Manassas, VA, USA) were grown in Ham's F12 nutrient medium, human prostate cancer DU145 cells (HTB-81, ATCC, Manassas, VA, USA) in RPMI 1640 medium and human colorectal carcinoma HCT116 cells (CCL-247, ATCC, Manassas, VA, USA) in IMDM medium. All media (Biowest, Nuaillé, France) were supplemented with $10 \%$ Foetal Bovine Serum (Gibco-Thermo Fisher Scientific, Waltham, MA, USA), L-glutamine, penicillin, and streptomycin (Euroclone, Milan, Italy), and grown at $37^{\circ} \mathrm{C}$ in a humidified $5 \% \mathrm{CO}_{2}$ atmosphere.

Synthesized curcumin, K3F compounds and docetaxel (MedChem Express, Monmouth Junction, NJ, USA) were dissolved in DMSO (Sigma-Aldrich, St. Louis, MO, USA) and added to cell medium at the concentrations described in the text for $48 \mathrm{~h}$. DMSO was used as control. Docetaxel IC50 values were calculated through MTT assay and estimated as $17 \mathrm{nM}$ and $30 \mathrm{nM}$ in DU145 and PC3, respectively.

\subsection{Cell Viability Assay}

The inhibition of cell proliferation was measured by colorimetric MTT assay [51] and the concentration at which cellular growth is inhibited by $50 \%$ (GI50) was determined. Briefly, cells were seeded into 96-well plates at a density of 2000 cells/well. The following day, cells were treated with the indicated compounds and analyzed for cell viability after $48 \mathrm{~h} .5 \mathrm{mg} / \mathrm{mL}$ thiazolyl blue tetrazolium bromide (Sigma-Aldrich, St. Louis, MO, USA) was added to each well at a final concentration of 0.5 $\mathrm{mg} / \mathrm{mL}$ and the plates were incubated at $37^{\circ} \mathrm{C}$ for $2 \mathrm{~h}$. Medium containing unconverted MTT was removed and $100 \mu \mathrm{L}$ MTT solvent $(4 \mathrm{mM} \mathrm{HCl}, 0.1 \% \mathrm{NP}-40$ in isopropyl alcohol) was added to each well. The plate was gently rotated on an orbital shaker in the dark for $15 \mathrm{~min}$, before the measurements of absorbance at $570 \mathrm{~nm}$. The viability of untreated cells was arbitrarily set at $100 \%$.

The ability of K3F21 and docetaxel to act synergistically with regard to growth inhibition was determined using CompuSyn software (ComboSyn, Inc., freely available at http: / www.combosyn. com) [34]. Combination index (CI) and drug reduction index (DRI) were calculated for each concentration of drugs mixture, as indicated in the text. $\mathrm{CI}<1,=1$ or $>1$ indicates synergism, additive effect, or antagonism, respectively. DRI $>1$ or $<1$ indicates favorable or not favorable dose-reduction.

\subsection{Anchorage-Dependent and-Independent Colony Formation Assay}

For anchorage-dependent colony formation assay, 1000 PC3 or 500 DU145 cells were plated in 6-well plates. Following overnight incubation, the cells were treated with curcumin or K3F21 $(2,5,10,20 \mu \mathrm{M})$ or with DMSO, as control. After 7-10 days, the plates were washed, fixed and stained with $0.5 \%$ crystal violet solution in $20 \%$ Methanol. Visible colonies with radius $\geq 3$ pixels were counted with automated colony counter (OpenCFU 3.9.0 software, freely available at http: // opencfu.sourceforge.net/) and plotted against curcumin concentrations. Colony numbers were normalized as a percentage of colonies formed following DMSO treatment.

For anchorage-independent colony formation assay, $0.6 \%$ low melt agarose gel with $10 \%$ FBS in appropriate complete cell growth medium was prepared and added to the wells of a twelve-well culture dish as a base agar. 1200 cells per well were plated in $0.25 \%$ (PC3) or $0.2 \%$ (DU145) agarose gel in appropriate complete cell growth medium supplemented with varying concentrations of curcumin and K3F21 $(5,10,20 \mu \mathrm{M})$ or with DMSO, as control. PC3 and DU145 cells were allowed to grow at 37 ${ }^{\circ} \mathrm{C}$ for three weeks (PC3) or five weeks (DU145). The effect of the drugs on anchorage-independent growth was determined by colony growth. Colonies were stained with $0.07 \%$ crystal violet and formed colonies were imaged. The numbers of colonies with radius $\geq 7$ pixels were counted with automated colony counter (OpenCFU 3.9.0) and average number of colonies was plotted against 
drug concentrations. Colony numbers were normalized as a percentage of colonies formed following DMSO treatment.

\subsection{Cell Cycle Analysis}

Cells were harvested after $48 \mathrm{~h}$ drug treatments and DNA distribution analysis of cells stained with propidium iodide solution (propidium iodide $25 \mu \mathrm{g} / \mathrm{mL}$, Na-Citrate $3.4 \mathrm{mM}, \mathrm{NaCl} 9.65 \mathrm{mM}$, NP-40 0.03\%) was performed by an Epics cytofluorimeter (Beckman Coulter Srl, Milan, Italy) [52,53].

\subsection{Cell Migration Assay}

$4 \times 10^{5}$ prostate cancer cells were plated in a 12-well plate. Approximately $24 \mathrm{~h}$ later, when the cells were $100 \%$ confluent, the monolayer was scratched using a $200 \mu \mathrm{L}$ pipette tip. Medium and non-adherent cells were removed and new medium containing 1\% FBS and GI50 concentrations of Curcumin, K3F21 and DTX was added. Cells were observed under the microscope and the inhibition of migration was assessed when the wound in the control was closed, after $16 \mathrm{~h}$ and $40 \mathrm{~h}$ in DU145 and PC3, respectively. Three biological replicates were performed. Three random pictures were taken for each treated well per experiment and the areas of the wounds measured using ImageJ software. The percentage of wound recovery was then calculated using the formula: (final area-initial area)/initial area $\times 100 \%$.

\subsection{Protein Extracts and Western Bot}

Whole-cell protein extracts were prepared by resuspending cells into 1X SDS sample buffer ( $25 \mathrm{mM}$ Tris-HCl pH 6.8, 1.5 mM EDTA, 20\% glycerol, 2\% SDS, 5\% $\beta$-mercaptoethanol, $0.0025 \%$ Bromophenol blue). Equivalent amounts of cellular extracts were resolved by SDS-PAGE, electrotransferred to PVDF membrane (GE Healthcare Italia, Milan, Italy) and immunoblotted with the following primary antibodies: anti-phospo-H2AX (sc-101696), anti-p53 (DO1) (sc-126), anti-actin (I19) (sc-1616) and anti-PARP (sc-8007) antibody from Santa Cruz Biotecnology, Inc, Dallas, TX, USA.; phospho-specific AKT antibody S473 (\#9018) and T308 (\#9275), Akt antibody (\#9272 and \#2967), phospho-specific ERK1/2 antibody T202/Y204 (\#4370), ERK1/2 antibody (\#4669), phospho-specific p38 MAPK antibody T180/Y182 (\#9211), and p38 antibody (\#9212) were purchased from Cell Signaling Technologies, Danvers, MA, USA. Membranes were blotted and scanned with Bio-Rad ChemiDocTM Touch Imaging System (Bio-Rad, Hercules, CA, USA), using chemiluminescent detection reagents from Cyanagen, Bologna, Italy (Westar $\eta \mathrm{C}$ and Supernova HRP substrates for Western blotting).

\subsection{RNA Extraction and RT-qPCR}

RNA was extracted from cells using RNeasy kit (Qiagen, Venlo, The Netherlands) and reversed transcribed with a Moloney murine leukemia virus reverse transcriptase (Promega, Madison, WI, USA). Quantitative real-time PCRs were performed using SsoAdvanced Universal SYBR Green Supermix (Bio-Rad, Hercules, CA, USA) on a Bio-Rad CFX Connect ${ }^{\mathrm{TM}}$ real-time PCR detection system. Primer sequences are available upon request. The housekeeping gene Rpl21 was used as a loading control. The relative fold change enrichments of real-time PCR samples were calculated with the formula $2^{-(\Delta \Delta \mathrm{Ct})}$, where $-(\Delta \Delta \mathrm{Ct})=-[(\mathrm{Ct}$ target $-\mathrm{Ct}$ Rpl21)treated $-(\mathrm{Ct}$ target $-\mathrm{Ct}$ Rpl21)DMSO $]$.

\subsection{Statistical Analysis}

Experiments were performed at least in biological triplicates and graphs represent mean \pm SEM values. All statistical analyses were performed using GraphPad PRISM v8 software (GraphPad Software, La Jolla, CA, USA), using two-tailed $t$-tests or one-sample $t$-tests, as appropriate. $p$ values of $p<0.05$ were considered to be statistically significant $\left(^{*}\right), p<0.01(* *), p<0.001\left(^{(* *)}\right.$, and $p<0.00011^{(* * *)}$. 
Supplementary Materials: Supplementary materials can be found at http:/ /www.mdpi.com/1422-0067/20/1/ 28/s1. Table S1: Logarithms of Protonation Constant $(\log \beta \mathrm{LH})$ and $\mathrm{pK}_{\mathrm{a}}$ values, Figure S1: UV-vis spectra of K3F21 on $\mathrm{pH}$ variation, Figure S2: Species distribution curves for ligands in the 3-9 $\mathrm{pH}$ range at [L]tot $=2 \times 10^{-4} \mathrm{M}$, Figure S3: Biological activity of K3-derivatives on human colorectal HCT116 cancer cells, Figure S4: Cell cycle analysis of PC3 and DU145 cells, Figure S5: Protein expression analysis of PCa cells following DTX administration. Figure S6: AIG colony assay in PCa cells.

Author Contributions: Conceptualization, E.F. and C.I.; Data curation, S.B.; Formal analysis, S.B.; Funding acquisition, E.F. and C.I.; Investigation, S.B. and G.O.; Methodology, S.B., G.O., V.S., G.R. and F.P.; Supervision, C.I.; Writing-review and editing, S.B., E.F. and C.I.

Funding: S.B. is a recipient of a three-year research fellowship from FIRC-AIRC (Associazione Italiana Ricerca Cancro), n. 19543. This work was supported in part by FAR 2015 grant to C.I. and E.F. by the University of Modena and Reggio Emilia. The research activity of C.I. laboratory was funded by AIRC (Associazione Italiana Ricerca Cancro), IG n. 14210.

Acknowledgments: We thank Serena Carra and Susanna Molinari at The University of Modena and Reggio Emilia for sharing anti-Akt and anti-p38 antibodies. We are grateful to Antonella Farsetti (Institute of Cell Biology and Neurobiology, CNR, Rome) for DU145 cell line.

Conflicts of Interest: The authors declare no conflict of interest.

\section{Abbreviations}

PCa Prostate cancer

AR Androgen receptor

DTX Docetaxel

DMSO Dimethylsulfoxide

CRPC Castration-resistant PCa

AIG Anchorage independent growth

\section{References}

1. Bray, F.; Ferlay, J.; Soerjomataram, I.; Siegel, R.L.; Torre, L.A.; Jemal, A. Global cancer statistics 2018: GLOBOCAN estimates of incidence and mortality worldwide for 36 cancers in 185 countries. CA Cancer J. Clin. 2018, 68, 394-424. [CrossRef] [PubMed]

2. Shen, M.M.; Abate-Shen, C. Molecular genetics of prostate cancer: New prospects for old challenges. Genes Dev. 2010, 24, 1967-2000. [CrossRef] [PubMed]

3. Quinn, D.I.; Sandler, H.M.; Horvath, L.G.; Goldkorn, A.; Eastham, J.A. The evolution of chemotherapy for the treatment of prostate cancer. Ann. Oncol. 2017, 28, 2658-2669. [CrossRef] [PubMed]

4. Ritch, C.R.; Cookson, M.S. Advances in the management of castration resistant prostate cancer. BMJ 2016. [CrossRef] [PubMed]

5. Yoo, S.; Choi, S.Y.; You, D.; Kim, C.-S. New drugs in prostate cancer. Prostate Int. 2016, 4, 37-42. [CrossRef] [PubMed]

6. Huang, M.T.; Wang, Z.Y.; Georgiadis, C.A.; Laskin, J.D.; Conney, A.H. Inhibitory effects of curcumin on tumor initiation by benzo[a]pyrene and 7,12-dimethylbenz[a]anthracene. Carcinogenesis 1992, 13, 2183-2186. [CrossRef] [PubMed]

7. Ravindran, J.; Prasad, S.; Aggarwal, B.B. Curcumin and cancer cells: How many ways can curry kill tumor cells selectively? AAPS J. 2009, 11, 495-510. [CrossRef] [PubMed]

8. Anand, P.; Sundaram, C.; Jhurani, S.; Kunnumakkara, A.B.; Aggarwal, B.B. Curcumin and cancer: AN old-age disease with an age-old solution. Cancer Lett. 2008, 267, 133-164. [CrossRef]

9. Tsui, K.-H.; Feng, T.-H.; Lin, C.-M.; Chang, P.-L.; Juang, H.-H. Curcumin blocks the activation of androgen and interlukin- 6 on prostate-specific antigen expression in human prostatic carcinoma cells. J. Androl. 2008, 29, 661-668. [CrossRef]

10. Teiten, M.-H.; Gaascht, F.; Eifes, S.; Dicato, M.; Diederich, M. Chemopreventive potential of curcumin in prostate cancer. Genes Nutr. 2010, 5, 61-74. [CrossRef]

11. Du, Y.; Long, Q.; Zhang, L.; Shi, Y.; Liu, X.; Li, X.; Guan, B.; Tian, Y.; Wang, X.; Li, L.; et al. Curcumin inhibits cancer-associated fibroblast-driven prostate cancer invasion through MAOA/mTOR/HIF-1alpha signaling. Int. J. Oncol. 2015, 47, 2064-2072. [CrossRef] [PubMed] 
12. Devassy, J.G.; Nwachukwu, I.D.; Jones, P.J.H. Curcumin and cancer: Barriers to obtaining a health claim. Nutr. Rev. 2015, 73, 155-165. [CrossRef] [PubMed]

13. Nelson, K.M.; Dahlin, J.L.; Bisson, J.; Graham, J.; Pauli, G.F.; Walters, M.A. The Essential Medicinal Chemistry of Curcumin. J. Med. Chem. 2017, 60, 1620-1637. [CrossRef] [PubMed]

14. Prati, F.; Bottegoni, G.; Bolognesi, M.L.; Cavalli, A. BACE-1 Inhibitors: From Recent Single-Target Molecules to Multitarget Compounds for Alzheimer's Disease. J. Med. Chem. 2018, 61, 619-637. [CrossRef] [PubMed]

15. Hu, W.; Huang, X.-S.; Wu, J.-F.; Yang, L.; Zheng, Y.-T.; Shen, Y.-M.; Li, Z.-Y.; Li, X. Discovery of Novel Topoisomerase II Inhibitors by Medicinal Chemistry Approaches. J. Med. Chem. 2018, 61, 8947-8980. [CrossRef] [PubMed]

16. Chen, R.; Wulff, J.E.; Moffitt, M.G. Microfluidic Processing Approach to Controlling Drug Delivery Properties of Curcumin-Loaded Block Copolymer Nanoparticles. Mol. Pharm. 2018, 15, 4517-4528. [CrossRef] [PubMed]

17. Matlinska, M.A.; Wasylishen, R.E.; Bernard, G.M.; Terskikh, V.V.; Brinkmann, A.; Michaelis, V.K. Capturing Elusive Polymorphs of Curcumin: A Structural Characterization and Computational Study. Cryst. Growth Des. 2018, 18, 5556-5563. [CrossRef]

18. Millrine, D.; Kishimoto, T. A Brighter Side to Thalidomide: Its Potential Use in Immunological Disorders. Trends Mol. Med. 2017, 23, 348-361. [CrossRef] [PubMed]

19. Ito, T.; Ando, H.; Suzuki, T.; Ogura, T.; Hotta, K.; Imamura, Y.; Yamaguchi, Y.; Handa, H. Identification of a primary target of thalidomide teratogenicity. Science 2010, 327, 1345-1350. [CrossRef]

20. Macpherson, G.R.; Franks, M.; Tomoaia-Cotisel, A.; Ando, Y.; Price, D.K.; Figg, W.D. Current status of thalidomide and its role in the treatment of metastatic prostate cancer. Crit. Rev. Oncol. Hematol. 2003, 46, S49-S57. [CrossRef]

21. Pabon, H.J.J. A synthesis of curcumin and related compounds. Recueil des Travaux Chimiques des Pays-Bas 2010, 83, 379-386. [CrossRef]

22. Ferrari, E.; Pignedoli, F.; Imbriano, C.; Marverti, G.; Basile, V.; Venturi, E.; Saladini, M. Newly synthesized curcumin derivatives: Crosstalk between chemico-physical properties and biological activity. J. Med. Chem. 2011, 54, 8066-8077. [CrossRef]

23. Ferrari, E.; Lazzari, S.; Marverti, G.; Pignedoli, F.; Spagnolo, F.; Saladini, M. Synthesis, cytotoxic and combined cDDP activity of new stable curcumin derivatives. Bioorg. Med. Chem. 2009, 17, 3043-3052. [CrossRef]

24. Basile, V.; Ferrari, E.; Lazzari, S.; Belluti, S.; Pignedoli, F.; Imbriano, C. Curcumin derivatives: Molecular basis of their anti-cancer activity. Biochem. Pharmacol. 2009, 78, 1305-1315. [CrossRef] [PubMed]

25. Dreicer, R. Chemotherapy for Advanced Prostate Cancer: Docetaxel and Beyond. Hematol. Oncol. Clin. N. Am. 2006, 20, 935-946. [CrossRef] [PubMed]

26. Dorai, T.; Cao, Y.C.; Dorai, B.; Buttyan, R.; Katz, A.E. Therapeutic potential of curcumin in human prostate cancer. III. Curcumin inhibits proliferation, induces apoptosis, and inhibits angiogenesis of LNCaP prostate cancer cells in vivo. Prostate 2001, 47, 293-303. [CrossRef] [PubMed]

27. Dorai, T.; Gehani, N.; Katz, A. Therapeutic potential of curcumin in human prostate cancer-I. curcumin induces apoptosis in both androgen-dependent and androgen-independent prostate cancer cells. Prostate Cancer Prostatic Dis. 2000, 3, 84-93. [CrossRef] [PubMed]

28. Rivera, M.; Ramos, Y.; Rodríguez-Valentín, M.; López-Acevedo, S.; Cubano, L.A.; Zou, J.; Zhang, Q.; Wang, G.; Boukli, N.M. Targeting multiple pro-apoptotic signaling pathways with curcumin in prostate cancer cells. PLoS ONE 2017, 12, E0179587. [CrossRef] [PubMed]

29. Taylor, B.S.; Schultz, N.; Hieronymus, H.; Gopalan, A.; Xiao, Y.; Carver, B.S.; Arora, V.K.; Kaushik, P.; Cerami, E.; Reva, B.; et al. Integrative genomic profiling of human prostate cancer. Cancer Cell 2010, 18, 11-22. [CrossRef] [PubMed]

30. Lee, J.T.; Steelman, L.S.; Chappell, W.H.; McCubrey, J.A. Akt inactivates ERK causing decreased response to chemotherapeutic drugs in advanced CaP cells. Cell Cycle 2008, 7, 631-636.

31. Schweyer, S.; Soruri, A.; Meschter, O.; Heintze, A.; Zschunke, F.; Miosge, N.; Thelen, P.; Schlott, T.; Radzun, H.J.; Fayyazi, A. Cisplatin-induced apoptosis in human malignant testicular germ cell lines depends on MEK/ERK activation. Br. J. Cancer 2004, 91, 589-598. [CrossRef]

32. Yeh, P.Y.; Chuang, S.-E.; Yeh, K.-H.; Song, Y.C.; Chang, L.L.-Y.; Cheng, A.-L. Phosphorylation of p53 on Thr55 by ERK2 is necessary for doxorubicin-induced p53 activation and cell death. Oncogene 2004, 23, 3580-3588. [CrossRef] [PubMed] 
33. Banerjee, S.; Singh, S.K.; Chowdhury, I.; Lillard, J.W.; Singh, R.; Singh, R. Combinatorial effect of curcumin with docetaxel modulates apoptotic and cell survival molecules in prostate cancer. Front. Biosci. 2017, 9, 235-245.

34. Chou, T.-C. Drug combination studies and their synergy quantification using the Chou-Talalay method. Cancer Res. 2010, 70, 440-446. [CrossRef] [PubMed]

35. Sleijfer, S.; Kruit, W.H.J.; Stoter, G. Thalidomide in solid tumours: The resurrection of an old drug. Eur. J. Cancer 2004, 40, 2377-2382. [CrossRef] [PubMed]

36. Drake, M.J.; Robson, W.; Mehta, P.; Schofield, I.; Neal, D.E.; Leung, H.Y. An open-label phase II study of low-dose thalidomide in androgen-independent prostate cancer. Br. J. Cancer 2003, 88, 822-827. [CrossRef] [PubMed]

37. Figg, W.D.; Dahut, W.; Duray, P.; Hamilton, M.; Tompkins, A.; Steinberg, S.M.; Jones, E.; Premkumar, A.; Linehan, W.M.; Floeter, M.K.; et al. A randomized phase II trial of thalidomide, an angiogenesis inhibitor, in patients with androgen-independent prostate cancer. Clin. Cancer Res. 2001, 7, 1888-1893.

38. Mukhopadhyay, A.; Bueso-Ramos, C.; Chatterjee, D.; Pantazis, P.; Aggarwal, B.B. Curcumin downregulates cell survival mechanisms in human prostate cancer cell lines. Oncogene 2001, 20, 7597-7609. [CrossRef] [PubMed]

39. Khor, T.O.; Keum, Y.-S.; Lin, W.; Kim, J.-H.; Hu, R.; Shen, G.; Xu, C.; Gopalakrishnan, A.; Reddy, B.; Zheng, X.; et al. Combined inhibitory effects of curcumin and phenethyl isothiocyanate on the growth of human PC-3 prostate xenografts in immunodeficient mice. Cancer Res. 2006, 66, 613-621. [CrossRef] [PubMed]

40. Ferrari, E.; Benassi, R.; Sacchi, S.; Pignedoli, F.; Asti, M.; Saladini, M. Curcumin derivatives as metal-chelating agents with potential multifunctional activity for pharmaceutical applications. J. Inorg. Biochem. 2014, 139, 38-48. [CrossRef] [PubMed]

41. Pascal, L.E.; Vêncio, R.Z.; Vessella, R.L.; Ware, C.B.; Vêncio, E.F.; Denyer, G.; Liu, A.Y. Lineage relationship of prostate cancer cell types based on gene expression. BMC Med. Genom 2011, 4, 46. [CrossRef] [PubMed]

42. Bookstein, R.; MacGrogan, D.; Hilsenbeck, S.G.; Sharkey, F.; Allred, D.C. p53 is mutated in a subset of advanced-stage prostate cancers. Cancer Res. 1993, 53, 3369-3373. [PubMed]

43. Oren, M.; Rotter, V. Mutant p53 gain-of-function in cancer. Cold Spring Harb. Perspect. Biol. 2010, 2, A001107.

44. Shaulian, E.; Zauberman, A.; Ginsberg, D.; Oren, M. Identification of a minimal transforming domain of p53: Negative dominance through abrogation of sequence-specific DNA binding. Mol. Cell. Biol. 1992, 12, 5581-5592. [CrossRef]

45. van Bokhoven, A.; Varella-Garcia, M.; Korch, C.; Johannes, W.U.; Smith, E.E.; Miller, H.L.; Nordeen, S.K.; Miller, G.J.; Lucia, M.S. Molecular characterization of human prostate carcinoma cell lines. Prostate 2003, 57, 205-225. [CrossRef] [PubMed]

46. Ghosh, P.M.; Malik, S.; Bedolla, R.; Kreisberg, J.I. Akt in prostate cancer: Possible role in androgen-independence. Curr. Drug Metab. 2003, 4, 487-496. [CrossRef] [PubMed]

47. Orteca, G.; Tavanti, F.; Bednarikova, Z.; Gazova, Z.; Rigillo, G.; Imbriano, C.; Basile, V.; Asti, M.; Rigamonti, L.; Saladini, M.; et al. Curcumin derivatives and A $\beta$-fibrillar aggregates: An interactions' study for diagnostic/therapeutic purposes in neurodegenerative diseases. Bioorg. Med. Chem. 2018, 26, 4288-4300. [CrossRef] [PubMed]

48. Gans, P.; Sabatini, A.; Vacca, A. Investigation of equilibria in solution. Determination of equilibrium constants with the HYPERQUAD suite of programs. Talanta 1996, 43, 1739-1753. [CrossRef]

49. Malavasi, G.; Ferrari, E.; Lusvardi, G.; Valentina, A.; Fantini, F.; Morterra, C.; Pignedoli, F.; Saladini, M.; Menabue, L. The role of coordination chemistry in the development of innovative gallium-based bioceramics: The case of curcumin. J. Mater. Chem. 2011, 21, 5027.

50. Szabo, M.; Idiţoiu, C.; Chambre, D.; Lupea, A. Improved DPPH determination for antioxidant activity spectrophotometric assay. Chem. Pap. 2007, 61, 214-216. [CrossRef]

51. Basile, V.; Baruffaldi, F.; Dolfini, D.; Belluti, S.; Benatti, P.; Ricci, L.; Artusi, V.; Tagliafico, E.; Mantovani, R.; Molinari, S.; et al. NF-YA splice variants have different roles on muscle differentiation. Biochim. Biophys. Acta 2016, 1859, 627-638. [CrossRef] [PubMed] 
52. Basile, V.; Belluti, S.; Ferrari, E.; Gozzoli, C.; Ganassi, S.; Quaglino, D.; Saladini, M.; Imbriano, C. Bis-Dehydroxy-Curcumin Triggers Mitochondrial-Associated Cell Death in Human Colon Cancer Cells through ER-Stress Induced Autophagy. PLoS ONE 2013, 8, E53664. [CrossRef] [PubMed]

53. Belluti, S.; Basile, V.; Benatti, P.; Ferrari, E.; Marverti, G.; Imbriano, C. Concurrent inhibition of enzymatic activity and NF-Y-mediated transcription of Topoisomerase-II $\alpha$ by bis-DemethoxyCurcumin in cancer cells. Cell Death Dis. 2013, 4, E756. [CrossRef] [PubMed]

2018 by the authors. Licensee MDPI, Basel, Switzerland. This article is an open access article distributed under the terms and conditions of the Creative Commons Attribution (CC BY) license (http://creativecommons.org/licenses/by/4.0/). 